\title{
O gênero Chara (Charophyceae, Characeae) das Regiões Metropolitanas de Salvador e de Feira de Santana, Bahia, Brasil
}

The genus Chara (Charophyceae, Characeae) of Metropolitan regions of Salvador and Feira de Santana, Bahia, Brazil

\author{
Camila dos Anjos Ribeiro ${ }^{1,4}$, Geraldo José Peixoto Ramos ${ }^{1}$, Norma Catarina Bueno ${ }^{2}$, \\ João Fernando Prado ${ }^{3} \&$ Carlos Wallace do Nascimento Moura ${ }^{1}$
}

\begin{abstract}
Resumo
O levantamento florístico do gênero Chara (Charophyceae, Characeae) nas Regiões Metropolitanas de Salvador e de Feira de Santana, foi realizado em 30 estações de coleta abrangendo seis municípios da RMS e seis da RMFS. Caracteres vegetativos e reprodutivos empregados na taxonomia do grupo foram analisados através de microscopia ótica e através de microscopia eletrônica de varredura dos oósporos. Foram identificadas seis espécies: C. diaphana, C. hydropitys, C. kenoyeri, C. martiana, C. rusbyana e C. zeylanica. Com exceção de C. hydropitys, reencontrada 186 anos após a primeira coleta na Bahia, os demais táxons são adições à ficoflora do estado. O emprego de microscopia eletrônica subsidiou a interpretação da ultraestrutura da parede do oósporo das espécies de Chara e a diferenciação de táxons morfologicamente semelhantes. A ultraestrutura da parede do oósporo de C. martiana é descrita pela primeira vez.
\end{abstract}

Palavras-chave: algas continentais, Charophyta, levantamento florístico, ultraestrutura do oósporo.

\begin{abstract}
The floristic survey of the genus Chara (Charophyceae, Characeae) in the Metropolitan Regions of Salvador and Feira de Santana, was carried out in 30 sampling station comprise six counties of RMS and six of RMFS. Vegetative and reproductive characters used in the taxonomy of the group were analyzed by optical microscopy and by scanning electron microscopy of oospores. Six species were identified: C. diaphana, $C$. hydropitys, C. kenoyeri, C. martiana, C. rusbyana, and C. zeylanica. Except C. hydropitys, rediscovered 186 years after the first citation for Bahia, all other taxa are additions to the phycoflora of Bahia state. The use of electron microscopy subsidized the interpretation of the ultrastructure of the oospore wall of the Chara species, and the differentiation of morphologically similar taxa. The ultrastructure of the wall of the oospore of C. martiana is described for the first time.
\end{abstract}

Key words: freshwater algae, Charophyta, floristic survey, oospore ultrastructure.

\section{Introdução}

Chara L. (Characeae, Charophyta) é constituído por algas macroscópicas eretas, sésseis, com entrenós e râmulos verticilados simples, cobertos por células corticais (com exceção de $C$. braunii C.C.Gmel. e C. bulbillifera (Donterberg) A.Garcia), presença de estipulóides arranjados em uma ou duas fileiras e núcula em posição superior ao glóbulo. São cosmopolitas, habitando lagos, lagoas, rios, tanques e córregos de água doce ou salobra e estão distribuídas em quase todos os continentes, em áreas temperadas e tropicais, exceto na Antártica (Wood \& Imahori 1965; Meiers et al. 1999).

\footnotetext{
${ }^{1}$ Universidade Estadual de Feira de Santana, Depto. Ciências Biológicas, Prog. Pós-graduação em Botânica, Av. Universitária, km 3, BR-116, 44031-460, Feira de Santana, BA, Brasil.

${ }^{2}$ Universidade Estadual do Oeste do Paraná, Prog. Pós-graduação em Conservação e Manejo de Recursos Naturais, R. Universitária 2019, Jardim Universitário, 85819-110, Cascavel, PR, Brasil.

${ }^{3}$ Universidade Federal do Rio Grande do Sul, Depto. Botânica, Av. Bento Gonçalves 9500, 91501-970, Porto Alegre, RS, Brasil.

${ }^{4}$ Autor para correspondência: caribeiro.bio@gmail.com
} 
De acordo com Nowak et al. (2016), a taxonomia das carofíceas é fundamentada, tradicionalmente, em um conceito fenético de espécie baseado nas semelhanças de caracteres morfológicos dos organismos. Alguns pesquisadores como Braun \& Nordstedt (1882), Groves \& Bullock-Webster (1924), Zaneveld (1940) e Krause (1997) categorizaram cada variação morfológica como espécies distintas. Wood \& Imahori (1965), na monografia mundial de Characeae, interpretaram que o gênero possuía poucas espécies com ampla gama de variações morfológicas e o subdividiram em subgêneros, seções e subseções, baseando-se em caracteres puramente morfológicos (Nowak et al. 2016; Borges \& Necchi-Junior 2017; Urbaniak \& Combik 2017). Esse arranjo embora ainda amplamente utilizado, tem sido questionado por trabalhos com enfoque molecular (Meiers et al. 1999; Sakayama et al. 2009; Schneider et al. 2015; Schneider et al. 2016; Nowak et al. 2016; Borges \& Necchi-Junior 2017).

Nas últimas décadas a ultraestrutura da parede do oósporo vem sendo empregada como uma ferramenta adicional na taxonomia do grupo (Casanova 2005). Dentre os vários aspectos do oósporo (largura, comprimento, fossa, estrias) o padrão de ornamentação da parede é considerado um dos mais importantes devido ao caráter conservado dessa estrutura (Ray et al. 2001). A utilização de Microscopia Eletrônica de Varredura (MEV) na análise da parede do oósporo, tem subsidiado alguns autores (John et al. 1990; Casanova 1997; Ray et al. 2001; Sakayama et al. 2009; Urbaniak 2011) a reverem e posicionarem alguns táxons considerados anteriormente por Wood (1962) e Wood \& Imahori $(1964,1965)$ em categoria infraespecífica, a nível de espécie.

No Brasil, pesquisas com Characeae tem como marco os trabalhos de Bicudo (1968, 1969, 1972, 1974, 1977, 1979) e Bicudo \& Yamaoka (1978), nos quais constam registros de táxons para vários estados brasileiros. Contudo, ainda hoje, a maioria dos trabalhos onde constam citação de Chara estão quase que restritos as regiões Sul (Astorino 1983; Prado 2003; Bueno et al.2011; Meurer \& Bueno 2012), Sudeste (Viera Junior et al. 2003; Picelli-Vicentim et al 2004; Borges \& Necchi-Junior 2017) e Centro-Oeste (Bueno et al. 1996; Borges \& Necchi-Junior 2017).

Informações sobre a ocorrência de Chara no estado da Bahia ainda são escassas e restritas aos trabalhos de Bicudo (1972, 1974), nos quais constam a citação de $C$. fibrosa C.Agardh ex
Bruzelius emend. R.D.Wood, C. fibrosa var. hydropitys f. hydropitys R.D.Wood, C. vulgaris L. e C. formosa C.B.Rob.

Diante desse cenário e da escassez de estudos taxonômicos de Characeae no estado, este estudo teve por objetivo inventariar os táxons de Chara das Regiões Metropolitanas de Feira de Santana (RMFS) e de Salvador (RMS), que apesar de abrigarem nove das 32 Áreas de Proteção Ambiental (APAs), vêm sofrendo constantes ações antrópicas decorrentes da expansão urbana e do turismo, os quais oferecem um sério risco aos recursos naturais e à biodiversidade.

\section{Materiais e Métodos}

O material estudado proveio de 30 estações de coleta abrangendo seis municípios da Região Metropolitana de Salvador e seis da Região Metropolitana de Feira de Santana (Fig.1).

O material foi coletado ao acaso, no período de abril de 2014 a abril de 2016, através de arranque manual ou com auxílio de rastelo ou gancho nas margens de lagoas, tanques (pequena área escavada para retenção de água para consumo animal e humano) e córregos de água doce propícios ao crescimento de carofíceas.

Durante as coletas, foram mensuradas algumas variáveis abióticas da água tais como $\mathrm{pH}$, temperatura $\left({ }^{\circ} \mathrm{C}\right)$, eletrocondutividade $(\mathrm{mS}$. $\mathrm{cm}^{-1}$ ) e sólidos totais dissolvidos (ppt) as quais foram obtidas com a sonda portátil da Hanna HI98130, enquanto o oxigênio dissolvido (mg.. $\mathrm{L}^{-1}$ ) foi mensurado com uma sonda digital Instrutherm (MO-910). Para cada espécie foram fornecidas as médias dessas variáveis bem como o desvio padrão.

Os caracteres vegetativos e reprodutivos empregados na taxonomia do grupo foram analisados através de estereomicroscópio (Leica S8AP0) e microscópio óptico (MO) (Olympus BX43).

Os oósporos, analisados através de $\mathrm{MO}$ e $\mathrm{MEV}$, foram removidos da planta com auxílio de estiletes sob estereomicroscópio, sendo, posteriormente, transferidos para eppendorfs e conservados com álcool a 70\%. Para a análise em MO, o material foi inicialmente clarificado com hipoclorito de sódio, lavados em água destilada, montados sobre lâmina e lamínula, e posteriormente analisados ao microscópio. Já a análise em MEV, seguiu a metodologia proposta por Pérez et al. (2014), com as seguintes modificações: (1) incubação com ácido acético glacial à temperatura ambiente durante $10 \mathrm{~min}$; (2) remoção do ácido 


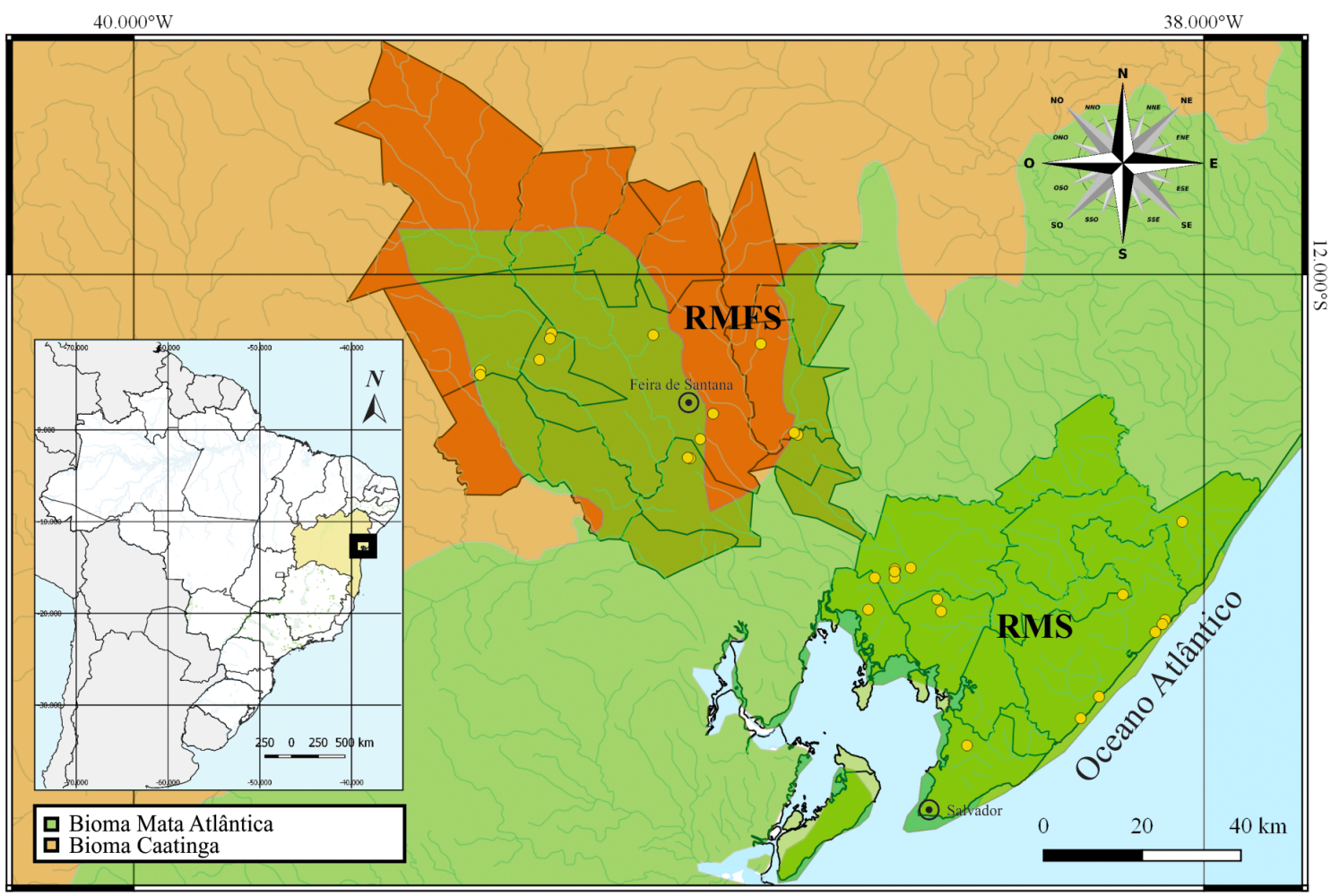

Figura 1 - Mapa das estações de coleta com ocorrência de Chara nas Regiões Metropolitanas de Feira de Santana (RMFS) e de Salvador (RMS), Bahia, Brasil.

Figure 1 - Map of colletion stations with occurrence of Chara in the Metropolitan Regions of Feira de Santana (RMFS) and Salvador (RMS), Bahia, Brazil.

acético glacial, e posterior incubação em solução de acetólise (9: 1 de anidrido acético: ácido sulfúrico concentrado) a $90{ }^{\circ} \mathrm{C}$ durante 10 minutos; (3) lavagem em solução de ácido acético glacial durante cinco minutos à temperatura ambiente; (4) sucessivas lavagens com água desionizada; e; (5) desidratado com duas lavagens de etanol a $100 \%$. Finalmente, os oósporos foram montados sobre stubs utilizando fita adesiva eletron condutora, metalizados com ouro e examinados no MEV marca JEOL 6390 LV.

A terminologia quanto a ornamentação da parede do oósporo em MO seguiu Wood \& Imahori (1965), ao passo que, para a caracterização em MEV adotou-se os trabalhos de John et al. (1990), Leitch et al. (1990), Faegri \& Iversen (1989), Sakayama et al. (2009), Mandal \& Ray (2004) Casanova (1997, 2005), Urbaniak (2011) e Borges \& Necchi-Junior (2017). Os nomes dos autores de táxons foram abreviados segundo Brummitt \& Powell (1992).

As microfotografias em MO foram obtidas com máquina fotográfica digital QIMAGING 5.0 acoplada ao microscópio óptico (MO) (Olympus BX43) utilizando software Image-Pro Premier 9.1.4.

As amostras estudadas estão depositadas no Herbário da Universidade Estadual de Feira de Santana (HUEFS).

\section{Resultados e Discussão}

Nas Regiões Metropolitanas de Feira de Santana e de Salvador foram identificadas seis espécies de Chara: C. diaphana, C. hydropitys, $C$. kenoyeri, C. martiana, C. rusbyana e C.zeylanica. Com exceção de $C$. hydropitys, reencontrada 186 anos após a primeira coleta na Bahia, os demais táxons estão sendo registrados pela primeira vez para o estado.

\section{Tratamento taxonômico}

Chara L., Species Plantarum, vol.2, p. 1153. 1753.

Plantas macroscópicas, hábito ereto e séssil, atingindo até $65 \mathrm{~cm}$ compr. Caulóide corticado, râmulos corticados e ecorticados, estipulóides haplostéfanos ou diplostéfanos. Râmulos 9-14, 
4-11 segmentados. Brácteas 4-9 nos nós dos râmulos. Bractéolas usualmente 2. Bracteletas 1, ocupando lugar dos glóbulos nas plantas dióicas. Gametângios conjuntos ou sejuntos. Glóbulo em posição inferior à núcula na planta. Oósporos elipsoidais, coloração preta, número de estrias de 9-12, fossas com padrão de ornamentação granulado, esponjoso e pustuloso em MEV.

\section{Chave de identificação das espécies de Chara estudadas}

1. Plantas dióicas.

2. Brácteas longas, 1.232-2.676 $\mu \mathrm{m}$ compr.; parede do oósporo (MEV) com grânulos densamente condensados, achatados, geralmente $2-3$ unidos... Chara kenoyeri

2'. Brácteas curtas, 444-1.156 $\mu \mathrm{m}$ compr.; parede do oósporo (MEV) com grânulos condensados, projetados, 0,9-1,5 $\mu \mathrm{m}$ compr., 0,2-0,5 $\mu \mathrm{m}$ diâm. Chara rusbyana

1'. Plantas monóicas.

3. Râmulos com segmentos intercalares corticados.

4. Gametângios sejuntos, nós basais dos râmulos sempre estéreis; parede do oósporo (MEV) esponjosa, constituída por fibrilas anastomosadas espessas Chara martiana

4'. Gametângios conjuntos, nós basais dos râmulos sempre férteis; parede do oósporo (MEV) com pústulas irregulares, com perfuração na porção central Chara zeylanica

3'. Râmulos com segmentos intercalares parcialmente corticados

5. Estipulóides haplostéfanos; parede do oósporo (MEV) com grânulos (Fig. 7h), ocasionalmente possuindo poros (Fig. 7i) . Chara hydropitys

5'. Estipulóides diplostéfanos; parede do oósporo (MEV) exibe discretas pontuações (aumentos $\leq 200 x$ ) e pústulas irregulares (aumento $>2.000 x$ ), pouco salientes, (Fig. 4h), com perfuração na porção central. Chara diaphana

Chara diaphana (Meyen) R.D.Wood in R.D.Wood \& K.Imahori, A revision of the Characeae 1, 768. 1965. Figs. $2 ; 3 ; 4$

Basônimo: Chara armata var. diaphana Meyen 1835.

Plantas monóicas, 19-66 cm compr., ásperas ao toque, incrustação calcárea forte principalmente nos râmulos verticilados e oósporos, entrenós curtos dando aspecto compacto a planta; brácteas visíveis a olho nu; caulóide 418-940 $\mu \mathrm{m}$ diâm.; entrenós $0,7-4,2 \mathrm{~cm}$ compr., córtex triplóstico nos entrenós e diplóstico nos râmulos; células espiniformes 61-385(-1.200) $\mu \mathrm{m}$ compr., 36-91 $\mu \mathrm{m}$ diâm., ápices acuminados-arredondados; estipulóides diplostéfanos, dois por râmulo verticilado, opostos a eles, ápices acuminadosarredondados, superiores $475-1.143 \mu \mathrm{m}$ compr., 66-126 $\mu \mathrm{m}$ diâm., estipulóides inferiores 206-605 $\mu \mathrm{m}$ compr., 51-108 $\mu \mathrm{m}$ diâm. Râmulos verticilados monomórficos, 10-12, 0,7-1,6 cm compr., 163$392 \mu \mathrm{m}$ diâm., segmentos 4-8; intercalares 1-3(-4) corticados; apicais ecorticados, acuminados, mais longos que as brácteas que os cercam, rodeados por 4-6 brácteas; segmento basal ecorticado 549$3.234 \mu \mathrm{m}$ compr., 295-434 $\mu \mathrm{m}$ diâm.; brácteas 4-8 verticiladas, 262-963(-1.258) $\mu \mathrm{m}$ compr.,
53-105 m diâm.; bractéolas 2, geralmente mais longas do que as núculas maduras, $886-1.576 \mu \mathrm{m}$ compr., 53-123 $\mu \mathrm{m}$ diâm.; bracteletas ausentes. Gametângios conjuntos, do $1^{\circ}$ ao $4^{\circ}$ nó basal; glóbulos alaranjados 304-441 $\mu \mathrm{m}$ diâm., com 4 escudos losangulares; núculas 540-835 $\mu \mathrm{m}$ compr., 205-452 $\mu \mathrm{m}$ diâm.; 10-12 convoluções,

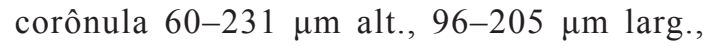
divergente.

Morfologia do oósporo: Oósporo elipsoide, preto, 10-12 estrias, 378-683 $\mu \mathrm{m}$ compr., 295-390 $\mu \mathrm{m}$ diâm., fossa 35-69 $\mu \mathrm{m}$ larg. Parede do oósporo em MO com padrão finamente granulado (Fig. 4f). Em MEV, em aumentos $\leq 200 x$ a parede exibe discretas pontuações (Fig. 4g), e em aumentos superiores $(>2.000 \mathrm{x})$ exibe pústulas irregulares, pouco salientes, de tamanho variado $(0,1-0,3$ $\mu \mathrm{m}$ diâm) (Fig. 4h), com perfuração na porção central (Fig. 4i). Estrias com o mesmo padrão de ornamentação das paredes das fossas; presença de borda expandida discreta.

Habitat: Plantas crescendo nas margens de lagos de fundo argiloso e areno-lodoso, associados a Gramineae, Cyperaceae, Salvinia sp., Utricularia sp., Nymphaea sp., Nitella sp. e Chara rusbyana M.Howe. 


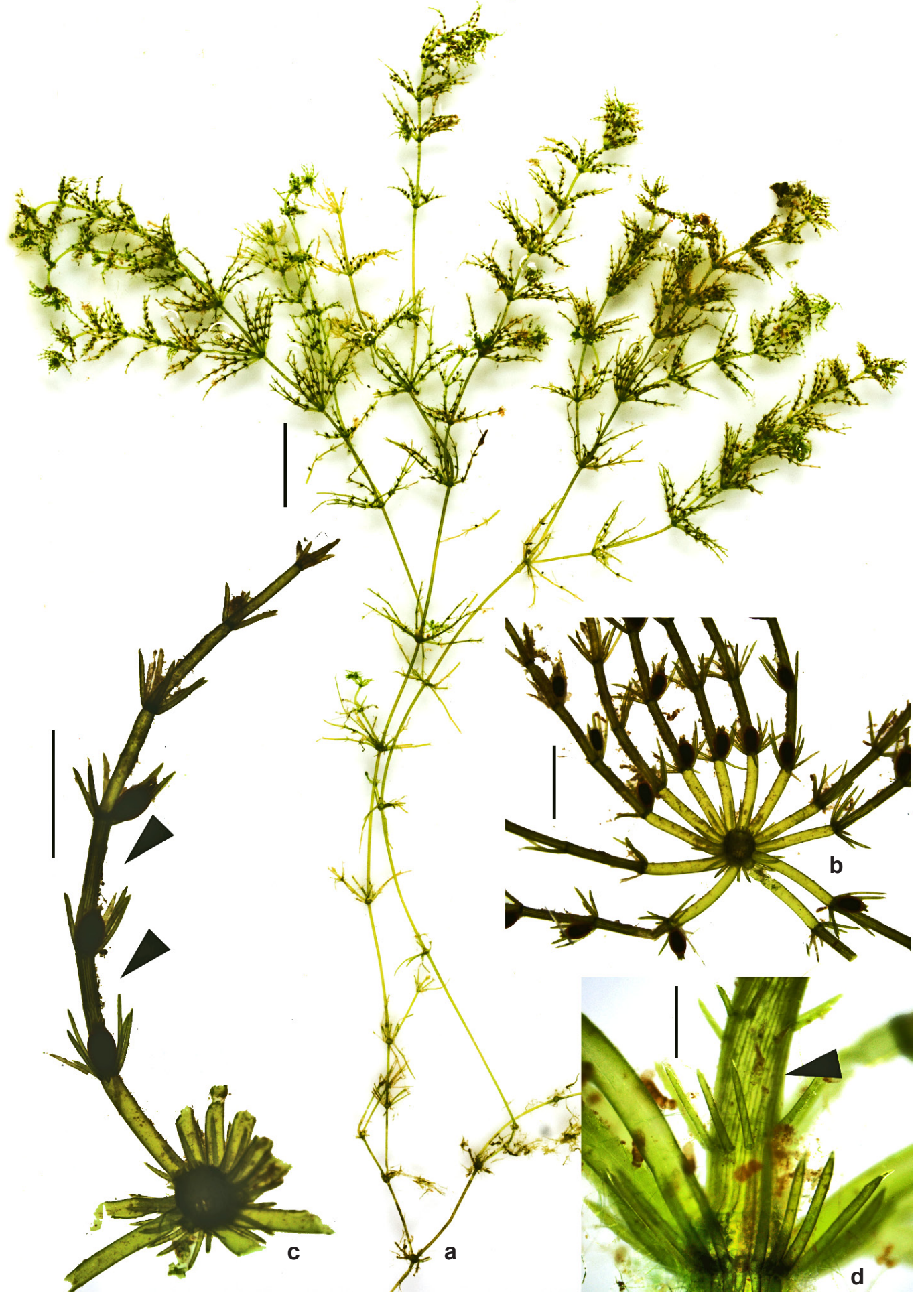

Figura 2 - a-d. Chara diaphana - a. hábito; b. verticilo fértil com râmulos apresentando segmentos basais ecorticado; c. detalhe do râmulo 6-segmentados com 2 segmentos corticados (setas) - note nós férteis; d. detalhe do nó mostrando saída de râmulos com segmentos basais ecorticados e entrenó corticado (seta). Barras: $\mathrm{a}=3 \mathrm{~cm} ; \mathrm{b}, \mathrm{c}=2 \mathrm{~mm} ; \mathrm{d}=0,5 \mathrm{~mm}$. Figure 2 - a-d. Chara diaphana - a. habit; b. fertile whorl with branchlet showing ecorticated basal segment; c. 6-segmented branchlet detail with 2 corticated segment (arrows) - note fertile nodes; d. node detail showing branchlets with ecorticated basal segment and corticated internodes (arrow). Bars: $\mathrm{a}=3 \mathrm{~cm} ; \mathrm{b}, \mathrm{c}=2 \mathrm{~mm} ; \mathrm{d}=0,5 \mathrm{~mm}$. 

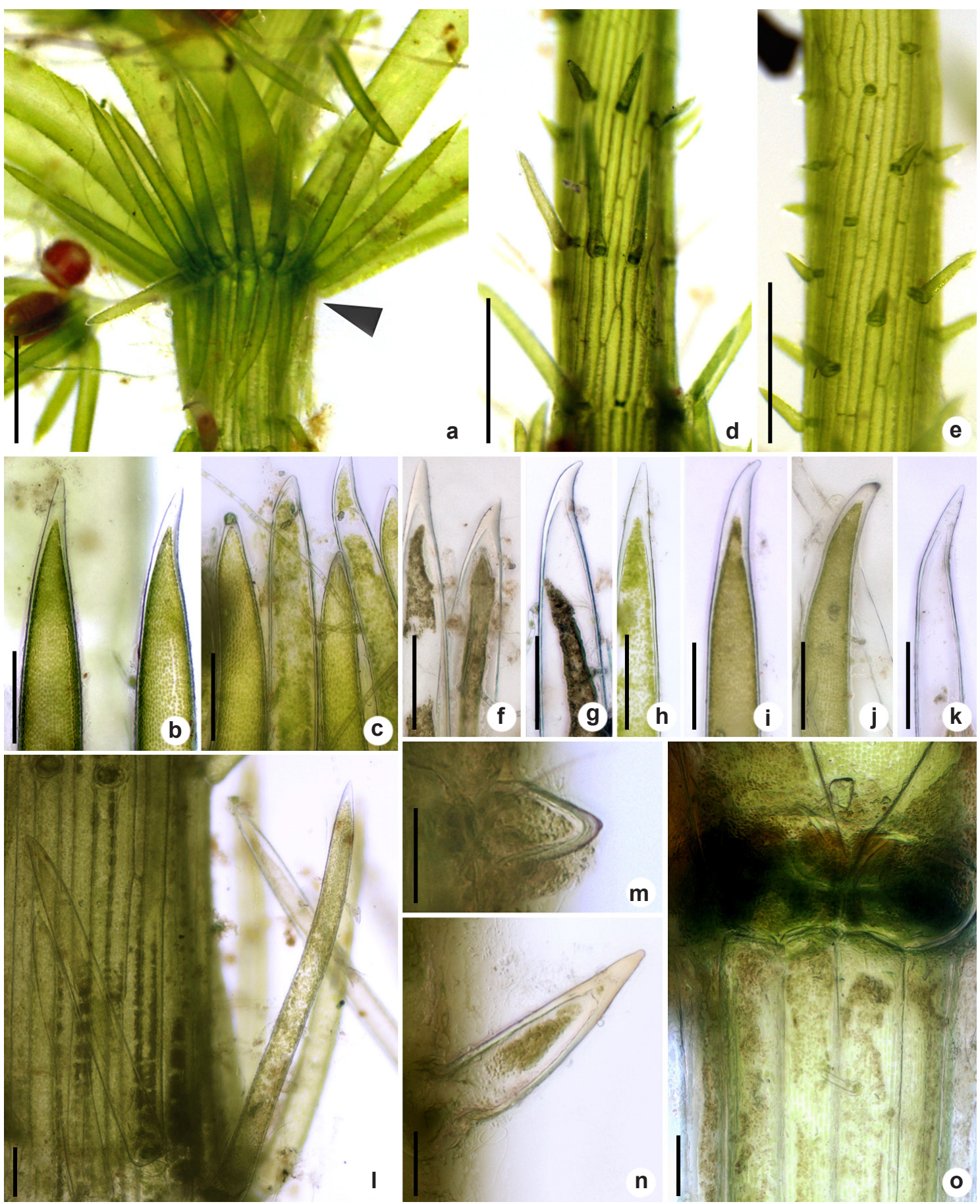

Figura 3 - a-o. Chara diaphana - a. estipulóides diplostéfanos (seta); b. estipulóides superiores com ápices acuminados; c. estipulóides inferiores de ápices acuminados-arredondados; d,e. detalhe da célula do entrenó com córtex triplóstico e células espiniformes isoladas de ápices acuminados; f-h. ápices acuminados das brácteas; i-k. ápices acuminados das bractéolas; 1 -n. células espiniformes com ápices acuminados-arredondados; o. detalhe de um râmulo com córtex diplóstico. Barras: a-c $=0,5 \mathrm{~mm} ; \mathrm{d}-\mathrm{l}=120 \mu \mathrm{m} ; \mathrm{m}-\mathrm{o}=50 \mu \mathrm{m}$.

Figure 3 - a-o. Chara diaphana - a. diplostephanous stipulodes (arrow); b. upper stipulodes with acuminate apex; c. lower stipulodes with acuminate-rounded apex; d,e. internode cell detail with triplostichous cortex and isolated spine cells with acuminate apex; f-h. bract cells acuminate apex; i-k. bracteoles acuminate apex; $1-\mathrm{n}$. spine cells with acuminate-rouded apex; o. branchlet detail with diplostichous córtex. Bars: a-c $=0,5 \mathrm{~mm} ; \mathrm{d}-\mathrm{l}=120 \mu \mathrm{m} ; \mathrm{m}-\mathrm{o}=50 \mu \mathrm{m}$. 

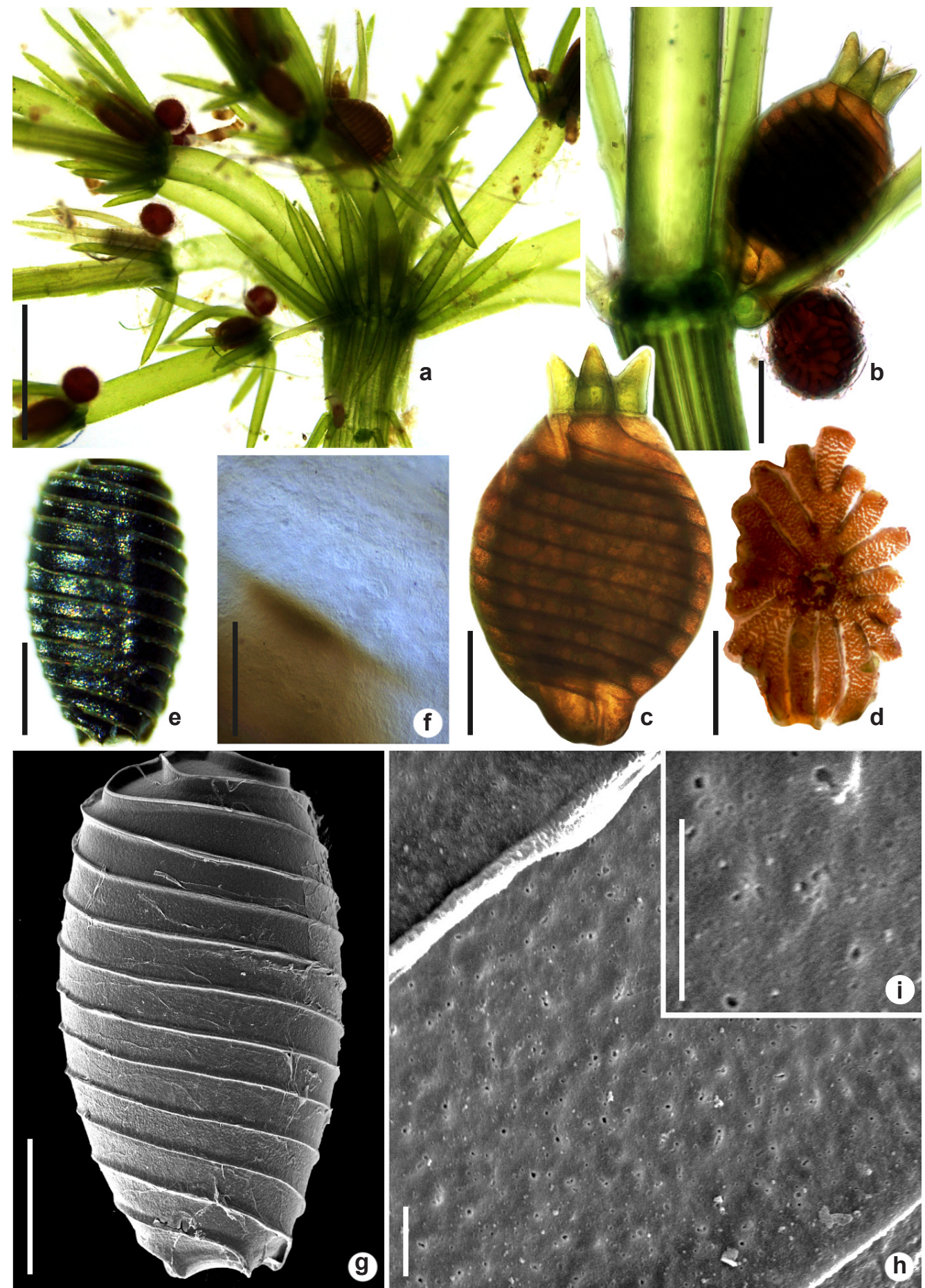

Figura 4 - a-i. Chara diaphana - a. detalhe do nó mostrando râmulos com nós basais férteis; b. detalhe de gametângios conjuntos - note glóbulo abaixo da núcula; c. núcula - note corônula divergente; d. escudo losangular; e. oósporo visto $\mathrm{MO} ;$ f. detalhe da parede do oósporo finamente granulada em MO; g. oósporo visto em MEV, parede exibindo discretas pústulas; h. detalhe da parede do oósporo pustulosa em MEV; i. detalhe das perfurações central das pústulas em MEV. Barras: $\mathrm{a}=1 \mathrm{~mm} ; \mathrm{b}-\mathrm{e}=200 \mu \mathrm{m} ; \mathrm{f}=30 \mu \mathrm{m} ; \mathrm{g}=100 \mu \mathrm{m} ; \mathrm{h}, \mathrm{i}=5 \mu \mathrm{m}$.

Figure 4 - a-i. Chara diaphana - a. node detail showing branchlets with fertile basal node; b. conjoined gametangia detail - note antheridium below oogonium; c. oogonium - note divergent coronula; d. lozenge-shaped scute; e. oospore (LM); f. granulate oospore wall (LM); g. oospore (SEM); h. pustular oospore wall in SEM; i. pustule central perforation in SEM. Bars: $\mathrm{a}=1 \mathrm{~mm} ; \mathrm{b}-\mathrm{e}=200 \mu \mathrm{m} ; \mathrm{f}=30 \mu \mathrm{m} ; \mathrm{g}=100 \mu \mathrm{m} ; \mathrm{h}, \mathrm{i}=5 \mu \mathrm{m}$. 
Variáveis abióticas da água $(\mathrm{n}=3)$ : Oxigênio dissolvido: $10,7 \pm 2,27$ mg. $\mathrm{L}^{-1}, \mathrm{pH}: 7,41 \pm$ 0,19 , sólidos totais dissolvidos: $0,30 \pm 0,31 \mathrm{ppt}$,

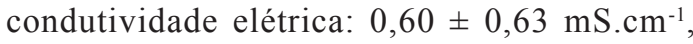
temperatura da água: $28,6 \pm 1,97{ }^{\circ} \mathrm{C}$, temperatura do ar: $27,9 \pm 1,6{ }^{\circ} \mathrm{C}$.

Materiais examinados: Camaçari, região metropolitana de Salvador, 2.X.2015, C.A.Ribeiro et al. (HUEFS 225705). Feira de Santana, região metropolitana de Feira de Santana, 13.X.2015, C.A. Ribeiro \& G.J.P. Ramos (HUEFS 225679). São Gonçalo dos Campos, 22.I.2015, C.A. Ribeiro \& G.J.P. Ramos (HUEFS 225682).

Distribuição geográfica no Brasil: Pará (Bicudo 1972), Pernambuco (Wood \& Imahori 1965 como Chara zeylanica var. diaphana Meyen ex Kütz.), Paraná (Bueno et al. 2011), Rio Grande do Sul (Prado 2003 como Chara zeylanica var. diaphana; Bueno et al. 2011); Bahia (presente estudo).

A presença de glóbulos com quatro escudos losangulares e estipulóides diplostéfanos aproxima C. diaphana de C. zeylanica Klein ex Willd., entretanto, esta é diferente por apresentar segmentos intercalares dos râmulos totalmente corticados.

Análises de MO dos oósporos revelaram padrão de ornamentação finamente granulado, semelhante aos registrados por Wood \& Imahori (1965), Bicudo (1972) e Prado (2003), embora as ilustrações fornecidas por este último apresentem grânulos mais evidentes quando comparados aos oósporos ora estudados.

As análises em MEV, ao contrário do padrão finamente granulado visto em MO, revelou padrão pustuloso, com presença de perfurações na porção central das pústulas. Cartajena \& Carmona (2009), realizaram análises em $\mathrm{MEV}$ do oósporo de $C$. diaphana (como C. zeylanica var. diaphana) do México, entretanto, não descreveram detalhes do padrão de ornamentação uma vez que não foi possível visualizar a parede da fossa com detalhes, provavelmente devido a artefato da técnica empregada.

Ray et al. (2001) e Mandal et al. (2002) identificaram padrão pustuloso ao estudarem populações de $C$. vulgaris, entretanto, as pústulas ilustradas por estes autores são mais proeminentes quando comparadas com o material da Bahia. Morfologicamente, C. vulgaris difere de $C$. diaphana por apresentar córtex diplóstico e brácteas unilaterais (Wood \& Imahori 1965).

Nas populações ora estudadas, observouse que o padrão de ornamentação da parede do oósporo de $C$. diaphana assemelha-se ao de $C$. zeylanica, tanto nas análises em MO quanto em MEV. Embora os táxons apresentem morfologias distintas, salienta-se a necessidade de ampliar amostragens a fim de verificar variações no padrão de ornamentação da parede do oósporo em MEV.

As populações analisadas estão de acordo com as descrições e ilustrações registradas por Wood \& Imahori (1965), Bicudo (1972,1974), Prado (2003, como Chara zeylanica var. diaphana) e Bueno et al. $(2009,2011)$.

É o primeiro registro da ocorrência da espécie para a Bahia e o segundo para o Nordeste do Brasil.

Chara hydropitys Rchb., in Möessler's Handbuch der Gewächskunde 3. 1669. 1834. Figs. 5; 6; 7

Plantas monóicas, 7,5-23 cm compr., coloração verde-escuro, ásperas ao toque, incrustação calcaria de moderada à forte, râmulos verticilados ligeiramente menores do que os entrenós; caulóide (199-)310-587(-747) $\mu \mathrm{m}$ diâm.; entrenós 1-2,5 cm compr., córtex triplóstico; células espiniformes da porção mediana do entrenó

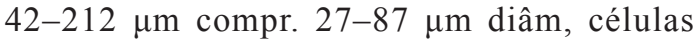
espiniformes acima do râmulo verticilado e abaixo dos estipulóides 400-732(-1.012) $\mu \mathrm{m}$ compr., 48$95 \mu \mathrm{m}$ diâm., ápices acuminados ou arredondados; estipulóides haplostéfanos, dois por râmulos verticilados, opostos a eles, de ápices acuminados,

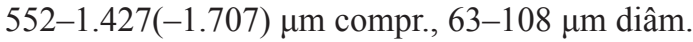
Râmulos verticilados monomórficos, 9-13, 0,8-2,5 cm compr., 146-325 $\mu \mathrm{m}$ diâm.; segmentos 6-9; intercalares (1-)2(-3-4) corticados; segmento basal ecorticado, 1.094-3.073 $\mu \mathrm{m}$ compr., 70-295 $\mu \mathrm{m}$; segmento apical ecorticado, maior do que as brácteas que o rodeiam, estas em número de 4-6; brácteas, 4-10 verticiladas, 440-1.389 $\mu \mathrm{m}$ compr., 70-123 $\mu \mathrm{m}$ diâm., ápices acuminados; bractéolas 2 mais longas do que as núculas maduras, 650-1.069(-1.440) $\mu \mathrm{m}$ compr., 42-146 $\mu \mathrm{m}$ diâm., ápices acuminados; bracteletas ausentes. Gametângios conjuntos, do $1^{\circ}$ ao $4^{\circ}$ nó basal; glóbulos alaranjados, 160-350 $\mu \mathrm{m}$ diâm., 8 escudos triangulares; núculas 375-929 $\mu \mathrm{m}$ compr.,

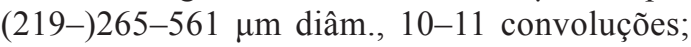
corônula 62-152 $\mu \mathrm{m}$ alt., 102-197 $\mu \mathrm{m}$ diâm., ápices levemente divergentes.

Morfologia do oósporo: Oósporo elipsoide, preto, com 9-11 estrias, 350-420(-560) $\mu \mathrm{m}$ compr.,

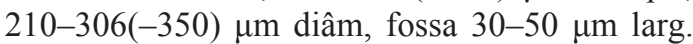
Parede do oósporo em MO e MEV com padrão granulado (Fig. 7e,f). Em MEV, em aumentos $\leq$ 300x a parede exibe discretas granulações (Fig. $7 \mathrm{f})$, e em aumentos superiores $(>2.000 \mathrm{x})$ a parede 


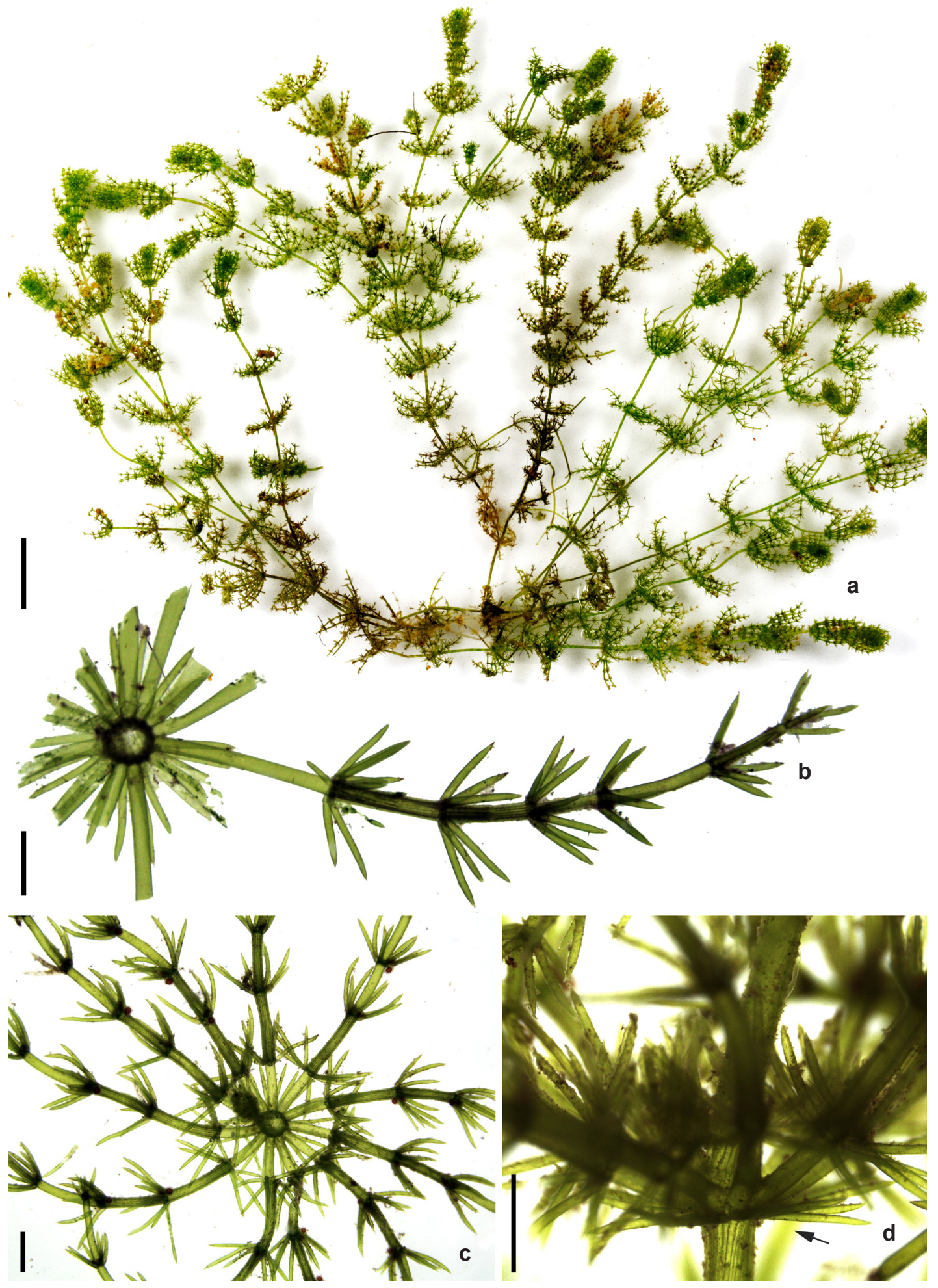

Figura 5 - a-d. Chara hydropitys - a. hábito; b. detalhe do râmulo 7-segmentado; c. verticilo de râmulos estéreis portando com segmentos basais ecorticados; d. detalhe do nó mostrando râmulos e estipulóides haplostéfanos (seta). Barras: $\mathrm{a}=3 \mathrm{~cm} ; \mathrm{b}-\mathrm{d}=1 \mathrm{~mm}$.

Figure 5 - a-d. Chara hydropitys - a. habit; b. 7-segmented branchlet; c. esterile branchlet whorl showing basal segments ecorticated; d. node detail showing branchlets and haplostephanous stipulodes (arrow). Bars: $\mathrm{a}=3 \mathrm{~cm} ; \mathrm{b}-\mathrm{d}=1 \mathrm{~mm}$. 

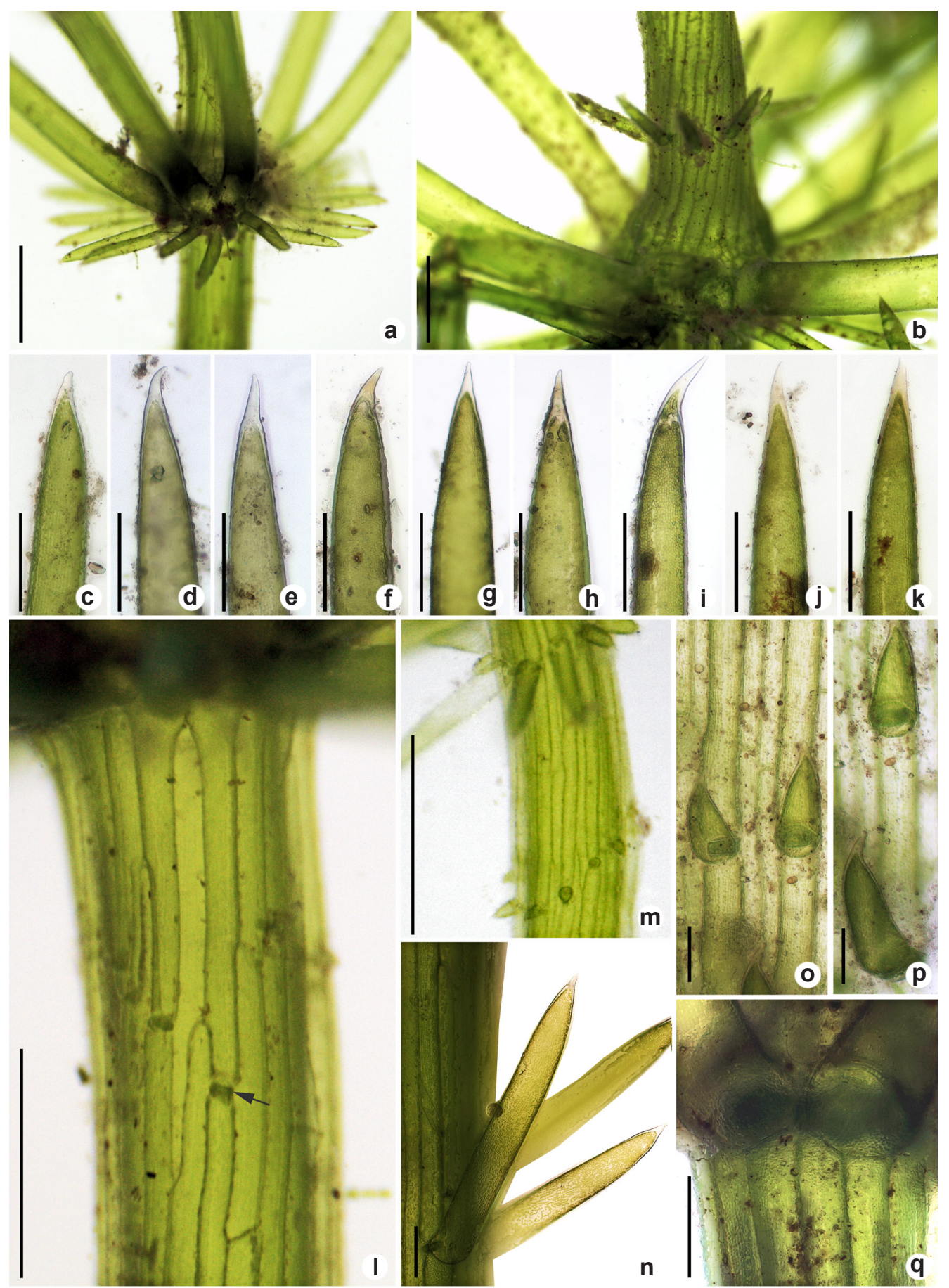

Figura 6 - a-q. Chara hydropitys - a. detalhe de estipulóides haplostéfanos; b. detalhe do entrenó com córtex triplóstico e células espiniformes; c-e. ápices acuminados dos estipulóides; f-h. ápices acuminados das brácteas; i-1. ápices acuminados das bractéolas; m,n. detalhe de córtex triplóstico - note cicatrizes de células espiniformes (seta); o,p. células espiniformes com ápices acuminados-arredondados; q. detalhe do râmulo com córtex triplóstico. Barras: $\mathrm{a}=1 \mathrm{~mm} ; \mathrm{b}, \mathrm{m}, \mathrm{n}=0,5 \mathrm{~mm} ; \mathrm{c}-1, \mathrm{o}-\mathrm{q}=120 \mu \mathrm{m}$.

Figure 6 - a-q. Chara hydropitys - a. haplostephanous stipulodes detail; b. internode detail with triplostichous cortex and spine cells; c-e. stipulodes acuminated apex; f-h. bract-cells acuminate apex; i-l. bracteoles acuminate apex; m,n. triplostichous cortex detail - note spine cells scars (arrow); o-q. spine cells with acuminate-rounded apex; r. branchlet detail with triplostichous cortex. Bars: a =1 mm; $\mathrm{b}, \mathrm{m}, \mathrm{n}=0,5 \mathrm{~mm} ; \mathrm{c}-1, \mathrm{o}-\mathrm{q}=120 \mu \mathrm{m}$. 


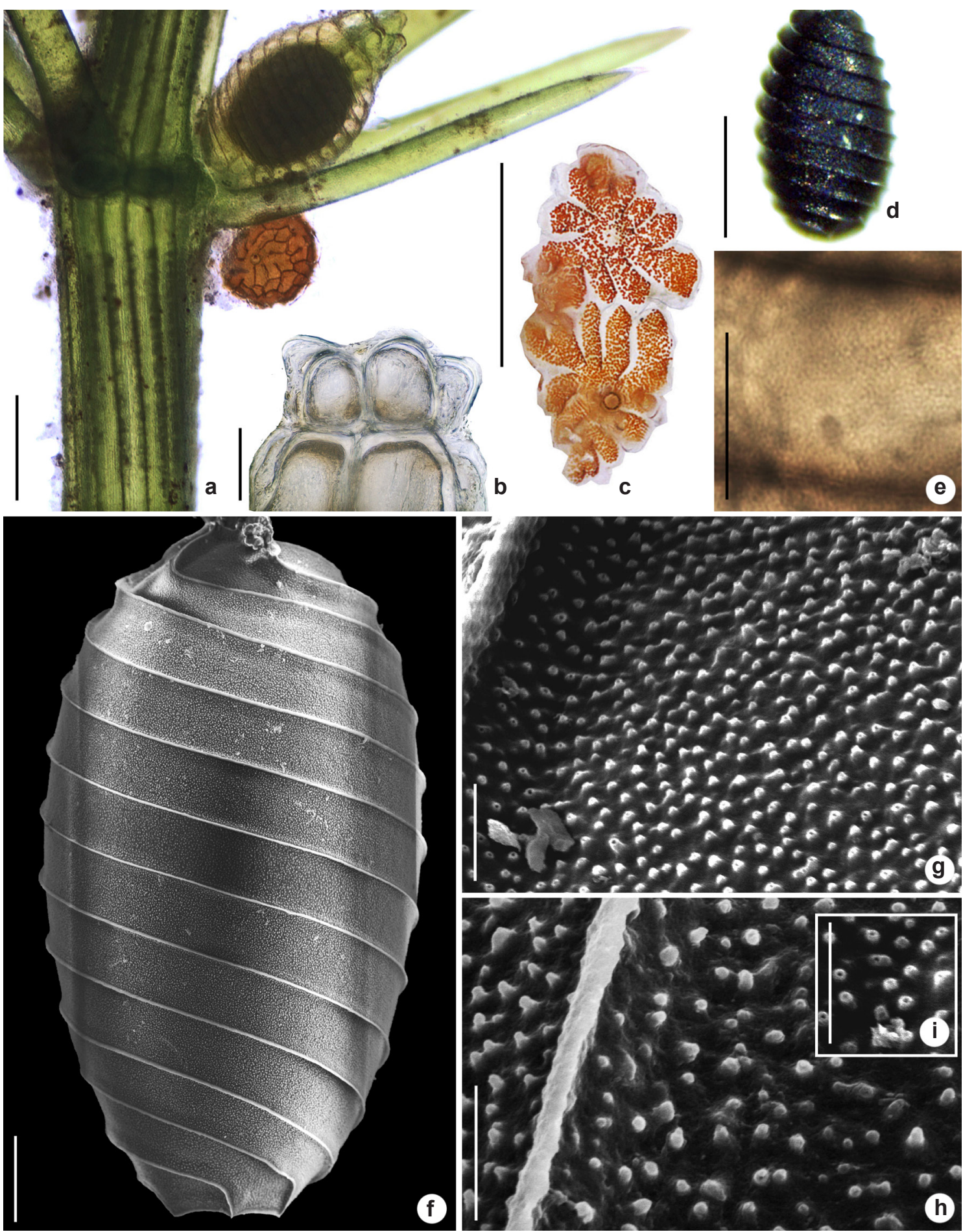

Figura 7 - a-i. Chara hydropitys - a. detalhe de gametângios conjuntos; b. detalhe de corônula divergente; c. escudos triangulares; d. oósporo visto em MO; e. detalhe da parede do oósporo granulada em MO; f. oósporo visto em MEV; g. parede do oósporo granulada em MEV; h. detalhe das projeções granulares em MEV; i. detalhe de grânulos com poros na região central. Barras: $\mathrm{a}, \mathrm{c}, \mathrm{d}=200 \mu \mathrm{m} ; \mathrm{b}=60 \mu \mathrm{m} ; \mathrm{e}=30 \mu \mathrm{m} ; \mathrm{f}=50 \mu \mathrm{m} ; \mathrm{g}-\mathrm{i}=5 \mu \mathrm{m}$.

Figure 7 - a-i. Chara hydropitys - a. conjoined gametangia detail; b. divergente coronula detail; c. triangular scute; d. oospore in LM; e. granular oospore wall detail in LM; f. oospore in SEM; g. granulate oospore wall in SEM; $h$. granules detail with central pore in SEM. Bars: $a, c, d=200 \mu \mathrm{m} ; \mathrm{b}=60 \mu \mathrm{m} ; \mathrm{e}=30 \mu \mathrm{m} ; \mathrm{f}=50 \mu \mathrm{m} ; \mathrm{g}-\mathrm{i}=5 \mu \mathrm{m}$. 
exibe grânulos com 0,3-0,6 بm diâm., distribuídos ao longo das fossas (Fig. 7g,h); região central do grânulo ocasionalmente possuindo poros (Fig. 7i). Estrias com rebordo expandido, ornamentadas com projeções granulares menos proeminentes quando comparadas com as da fossa.

Habitat: Na área estudada encontrada crescendo nas margens de lagoas de fundo argiloso, argilosolodoso e areno-lodoso, associados a Gramineae, Cyperaceae Utricularia sp., Elodea sp. e Nitella sp. Variáveis abióticas da água $(\mathrm{n}=11)$ : Oxigênio dissolvido: $6,34 \pm 3,91 \mathrm{mg} \cdot \mathrm{L}^{-1}, \mathrm{pH}: 6,95 \pm$ 0,53, sólidos totais dissolvidos: $0,37 \pm 0,54 \mathrm{ppt}$, condutividade elétrica: $0,75 \pm 1,07 \mathrm{mS} . \mathrm{cm}^{-1}$, temperatura: $31,5 \pm 1,06{ }^{\circ} \mathrm{C}$.

Material examinados: Camaçari, região metropolitana de Salvador, 2.X.2015, C.A. Ribeiro et al. (HUEFS 225701); 1.III.2016, C.A. Ribeiro et al. (HUEFS 225708). Candeias, 8.IX.2014, M.A. Santos et al. (HUEFS 225660, HUEFS 225661); 1.IV.2016, C.A. Ribeiro \& G.J.P. Ramos (HUEFS 225713). Coração de Maria, região metropolitana de Feira de Santana, 19.II.2016, C.A. Ribeiro \& G.J.P. Ramos (HUEFS 225692). Feira de Santana, 6.VIII.2015, C.A. Ribeiro et al. (HUEFS 225663). São Francisco do Conde 8.IX.2014, M.A. Santos et al. (HUEFS 225658). São Sebastião do Passé, 8.IX.2014, M.A. Santos et al. (HUEFS 225653, HUEFS 225654, HUEFS 225657).

Distribuição geográfica no Brasil (como Chara fibrosa var. hydropitys f. hydropitys (Rchb.) R.D.Wood): Maranhão (Bicudo 1972,1974), Pernambuco (Siqueira-filho \& Bueno 2012), Bahia (Braun \& Nordstedt 1882 como C. hydropitys var. genuina A.Braun; Bicudo 1972, 1974), Mato Grosso do Sul (Bicudo 1972, 1974; Bueno et al. 1996; Bueno et al. 2009; Borges \& Necchi-Junior 2017), Rio Grande do Sul (Astorino 1983; Torgan et al. 2001; Prado 2003; Bueno et al. 2011 como C. hydropitys).

De acordo com Bicudo (1972), C. hydropitys foi o primeiro táxon de Charophyceae coletado no Brasil. O registro foi realizado por Salzmann em 1830 em uma localidade não especificada no estado da Bahia, sendo inicialmente identificado como $C$. longibractea Salzmann. Posteriormente, Zaneveld (1940) tratou esse registro (C. longibracteata Salzmann non Kütz., Pl.venal.Brasil.1830, n 743), como sinônimo de Chara hydropitys.

Chara hydropitys lembra, morfologicamente, C. diaphana por possuir corticação pouco desenvolvida nos segmentos intercalares, entretanto, este último difere por apresentar estipulóides diplostéfanos. O táxon ainda é morfologicamente próximo à $C$. fibrosa C.Agardh ex Bruzelius, mas esta difere pela total ausência de corticação nos râmulos verticilados.

$\mathrm{Na}$ literatura, alguns autores trataram $C$. hydropitys como uma variedade de C. fibrosa (Wood \& Imahori 1965; Bicudo 1972; Astorino 1983; Bueno et al. 1996; Prado 2003; Bueno et al. 2009). Entretanto, Meiers et al. (1999), realizando estudos moleculares empregando marcador $18 \mathrm{~S}$ rRNA demonstraram que $C$. hydropitys não está relacionada com $C$. fibrosa, uma vez que foram posicionados em clados distintos. Por esta razão considerou-se $C$. hydropitys distinta de C. fibrosa.

A variedade típica de $C$. hydropitys é próxima de $C$. hydropitys var. mexicana Allen, uma vez que estas apresentam sobreposição de características morfológicas e métricas, diferindo apenas na quantidade de segmentos intercalares corticados do râmulos verticilados que, de acordo com Wood \& Imahori (1965), são até dois na variedade típica, e de três a quatro na var. mexicana. Bicudo (1972) descreveu plantas da var. mexicana ocorrendo no Ceará com apenas o segundo segmento dos râmulos corticados e os demais nus.

John et al. (1990), baseados nas características da parede do oósporo visualizadas em MEV diferenciam C. hydropitys e C.gymnopitys A.Braun (= C.fibrosa C.Agardh ex Bruzelius): a primeira apresentando padrão granular e a segunda, padrão fibroso.

A parede do oósporo estudados em $\mathrm{MO}$ e MEV apresentaram padrão de ornamentação granulado, com região central do grânulo ocasionalmente possuindo poros quando visualizados em MEV. O padrão observado em MEV foi similar ao descrito por Borges \& Necchi-Junior (2017), entretanto, os autores não observaram poros na porção central dos grânulos, devido à limitação de aumento utilizado pelos autores.

O resultado obtido em $\mathrm{MO}$ para o padrão da parede do oósporo discorda dos descritos por Wood \& Imahori (1965), Astorino (1983) e Bueno et al. (2011) que documentaram a parede lisa, e em parte com os descritos por Bueno et al. (1996) e Bueno et al. (2009), que registraram o padrão irregularmente granulado.

As populações estudadas concordam com as descrições e ilustrações relatadas para as plantas brasileiras (Astorino 1983 como C. fibrosa var. hydropitys f. hydropitys; Prado 2003 como $C$. fibrosa var. hydropitys f. hydropitys e Bueno et al. 1996, 2009, como C. fibrosa var. hydropitys $\mathrm{f}$. hydropitys; Bueno et al. 2011). 
O táxon foi recoletado na Bahia 186 anos após a coleta de Salzman em 1830.

Chara kenoyeri M.Howe, Field Museum of Natural History: Botanical series 4(6): 159, pl. 16. 1929.

Figs. $8 ; 9 ; 10$

Plantas dióicas, 8-17 cm alt.; caulóide 391-649 $\mu \mathrm{m}$ diâm., entrenós 1,5-4,1 cm compr, incrustação calcárea presente; córtex triplóstico, diplóstico no râmulo; células espiniformes solitárias 163-288 $\mu \mathrm{m}$ compr., 32-58 $\mu \mathrm{m}$ diâm.; estipulódios diplostéfanos, 2 por râmulo, opostos a eles, estipulódios superiores 765-971 $\mu \mathrm{m}$ compr., 57-90 ㅆm diâm., estipulódios inferiores 597-713 $\mu \mathrm{m}$ compr., 38-70 $\mu \mathrm{m}$ diâm. Râmulos verticilados monomórficos, 13-14, 1-2,1 cm compr., 299-330 بm diâm.; segmentos 10-11; intercalares 9-10 corticados; apicais ecorticados, acuminados, mais longos que as brácteas que os cercam, rodeados por 4-5 brácteas; segmento basal ecorticado 991-1.243 $\mu \mathrm{m}$ compr., 257-315 $\mu \mathrm{m}$ diâm.; brácteas 5-9 verticiladas, 1.232-2.676 $\mu \mathrm{m}$ compr., 91-116 $\mu \mathrm{m}$ diâm, ápice acuminado; bractéolas 1.584-1.776 $\mu \mathrm{m}$ compr., 93-129, ápices acuminados; bracteletas $1.565-1.800 \mu \mathrm{m}$ compr., 96-111 $\mu \mathrm{m}$ diâm, ápices acuminados. Gametângios em plantas separadas, do $2^{\circ}$ ao $5^{\circ}$ nó basal; glóbulos 738-749 $\mu \mathrm{m}$ diâm., com 8 escudos triangulares; núculas $806-913 \mu \mathrm{m}$ compr., 530-644 بm diâm.; 11-12 convulações, corônula 98-159 $\mu \mathrm{m}$ alt., $182-238 \mu \mathrm{m}$ larg., divergente.

Morfologia do oósporo: Oósporo elipsoide, preto, incrustados com carbonato de cálcio, 11-12 estrias, 546-650 $\mu \mathrm{m}$ compr., 344-405 $\mu \mathrm{m}$ diâm., fossa 50-69 $\mu \mathrm{m}$ larg. Parede do oósporo em MO e MEV com padrão de ornamentação granulado (Fig. 10f,g). Em MEV, em aumentos $\leq 200 x$, a parede exibe discretos grânulos (Fig. $10 \mathrm{~g})$, e em aumentos superiores $(>2.000 \mathrm{x})$ exibe grânulos densamente condensados, de formatos variados, achatados, 0,4-1,3 $\mu \mathrm{m}$ diâm., geralmente 2-3 unidos (Fig. 10h,i), distribuídos ao longo das fossas do oósporo. Estrias seguindo o mesmo padrão de ornamentação das paredes das fossas; presença de borda expandida bastante proeminente, rugosa possuindo perfurações Habitat: Plantas crescendo nas margens de tanques de fundo lodoso, areno-lodoso e argiloso, associados a Gramineae, Chara zeylanica Klein ex Willd., Nitella sp., Chara martiana Wallman. Variáveis abióticas da água $(\mathrm{n}=3)$ : Oxigênio dissolvido: $6,75 \pm 0,75 \mathrm{mg} . \mathrm{L}^{-1}, \mathrm{pH}: 8,37 \pm$ 0,94 , sólidos totais dissolvidos: $0,13 \pm 0,06 \mathrm{ppt}$, condutividade elétrica: $0,26 \pm 0,11 \mathrm{mS} \cdot \mathrm{cm}^{-1}$, temperatura: $31,8 \pm 0,30{ }^{\circ} \mathrm{C}$.

Materiais examinados: Camaçari, região metropolitana de Salvador, 2.X.2015, C.A. Ribeiro et al. (HUEFS 225704). Conceição do Jacuípe, região metropolitana de Feira de Santana, 19.II.2016, C.A. Ribeiro \& G.J.P. Ramos (HUEFS 225688). Feira de Santana, 18.IX.2015, C.A. Ribeiro et al. (HUEFS 225664).

Distribuição geográfica no Brasil: Pernambuco (Siqueira-Filho \& Bueno 2012), Espirito Santo (Bicudo 1972, 1974; Proctor et al. 1971), Minas Gerais (Bicudo 1972, 1974), Goiás (Wood \& Imahori 1965; Bicudo 1972, 1974,), Mato Grosso do Sul (Bueno et al. 2009), Paraná (Bueno et al. 2011), Bahia (presente estudo).

Chara kenoyeri é morfologicamente próxima à Chara rusbyana $\mathrm{M}$.Howe, mas esta difere por possuir brácteas menores (444-1.156 $\mu \mathrm{m}$ compr.) e menor número râmulos verticilados (9-10).

A ornamentação da parede do oósporo em MEV manteve o mesmo padrão granulado visualizado em MO, entretanto foi possível observar que os grânulos geralmente são unidos (2-3). Cáceres (1979), também relatou o padrão granulado da parede do oósporo de $C$. kenoyeri provenientes da Argentina, embora este difira por apresentar grânulos mais proeminentes.

As plantas estudadas concordam com as descrições e ilustrações fornecidas por Wood \& Imahori [1965, como Chara zeylanica var. zeylanica f. kenoyeri (M.Howe) R.D.Wood], Bicudo (1972, 1974) e Bueno et al. (2009, 2011). No Brasil, plantas masculinas foram documentadas por Bicudo $(1972,1974)$ para o Espírito Santo e Bueno et al. (2011) para o Paraná, ao passo que plantas femininas foram registradas por Bueno et al. (2009) para o Mato Grosso do Sul.

O presente estudo é o primeiro registro da ocorrência para a Bahia e o segundo para o Nordeste do Brasil.

Chara martiana Wallman, Försök till en systematisk uppställning af växfamiljen Characeae. 66, pl.7. 1853.

Figs. $11 ; 12 ; 13$

Plantas monóicas, 9-18 cm compr., de coloração verde escura; entrenós mais curtos em direção ao ápice da planta, os dois últimos verticilos apicais e o broto apical são envolvidos pelo antepenúltimo verticilo; incrustação calcárea moderada; caulóide 374-566 $\mu$ m diâm.; entrenós 1,6-3,6 cm compr., córtex triplóstico; células espiniformes solitárias 78-224 $\mu \mathrm{m}$ compr., 28-77 


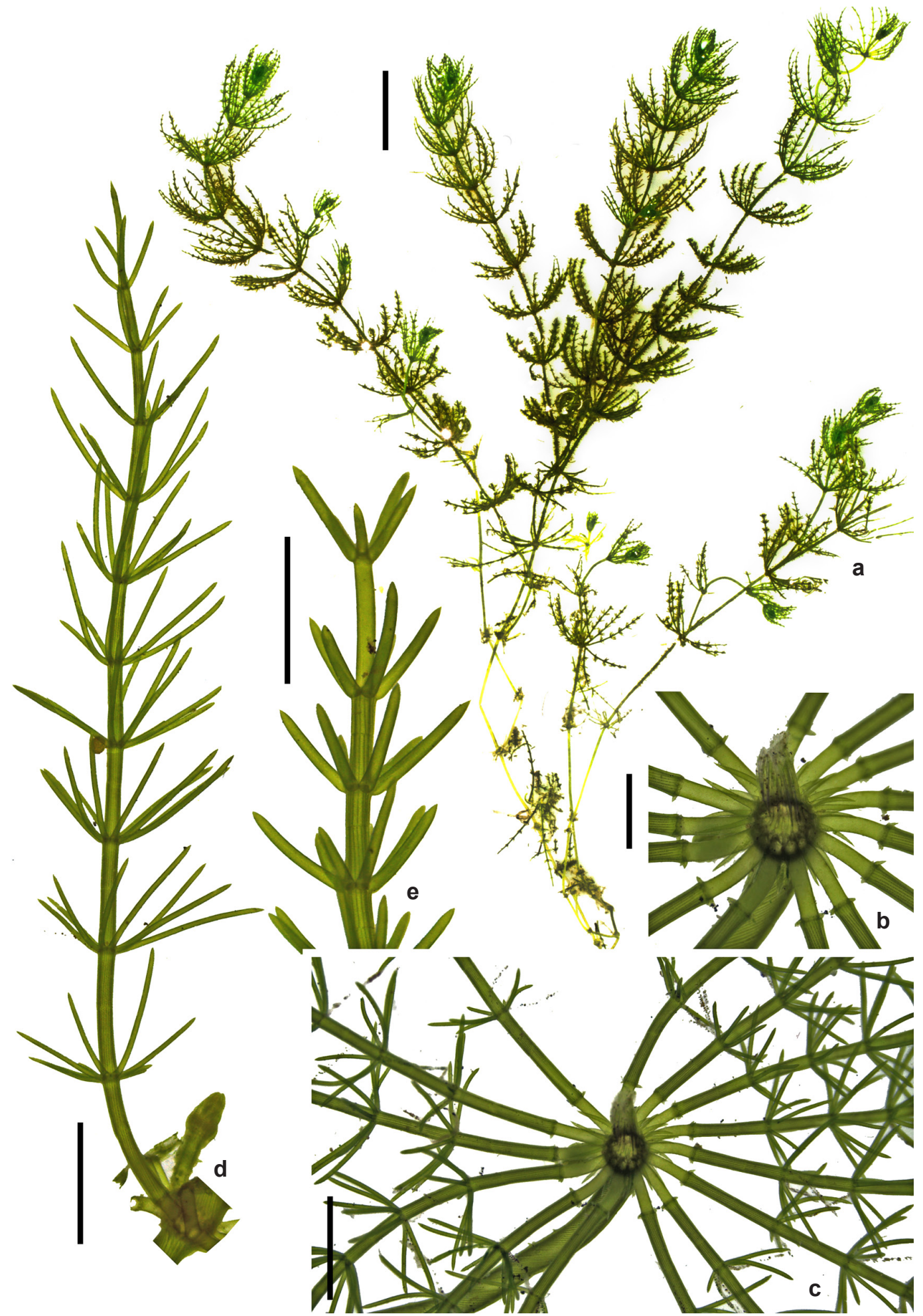

Figura 8 - a-e. Chara kenoyeri - a. hábito; b. verticilo de râmulos estéreis com segmentos basais ecorticados; c. detalhe do verticilo de râmulos, note brácteas alongadas; d. detalhe do râmulo 12-segmentado; e. detalhe do segmento apical. Barras: $\mathrm{a}=3 \mathrm{~cm} ; \mathrm{b}, \mathrm{e}=1 \mathrm{~mm} ; \mathrm{c}, \mathrm{d}=2 \mathrm{~mm}$.

Figure 8 - a-e. Chara kenoyeri - a. habit; b. esterile branchlet whorl showing ecorticated basal segments; c. branchlet whorl detail, note elongated bract-cells; d. 12-segmented branchlet detail of the; e. apical segment detail. Bars: $\mathrm{a}=3 \mathrm{~cm} ; \mathrm{b}, \mathrm{e}=1 \mathrm{~mm} ; \mathrm{c}, \mathrm{d}=2 \mathrm{~mm}$. 

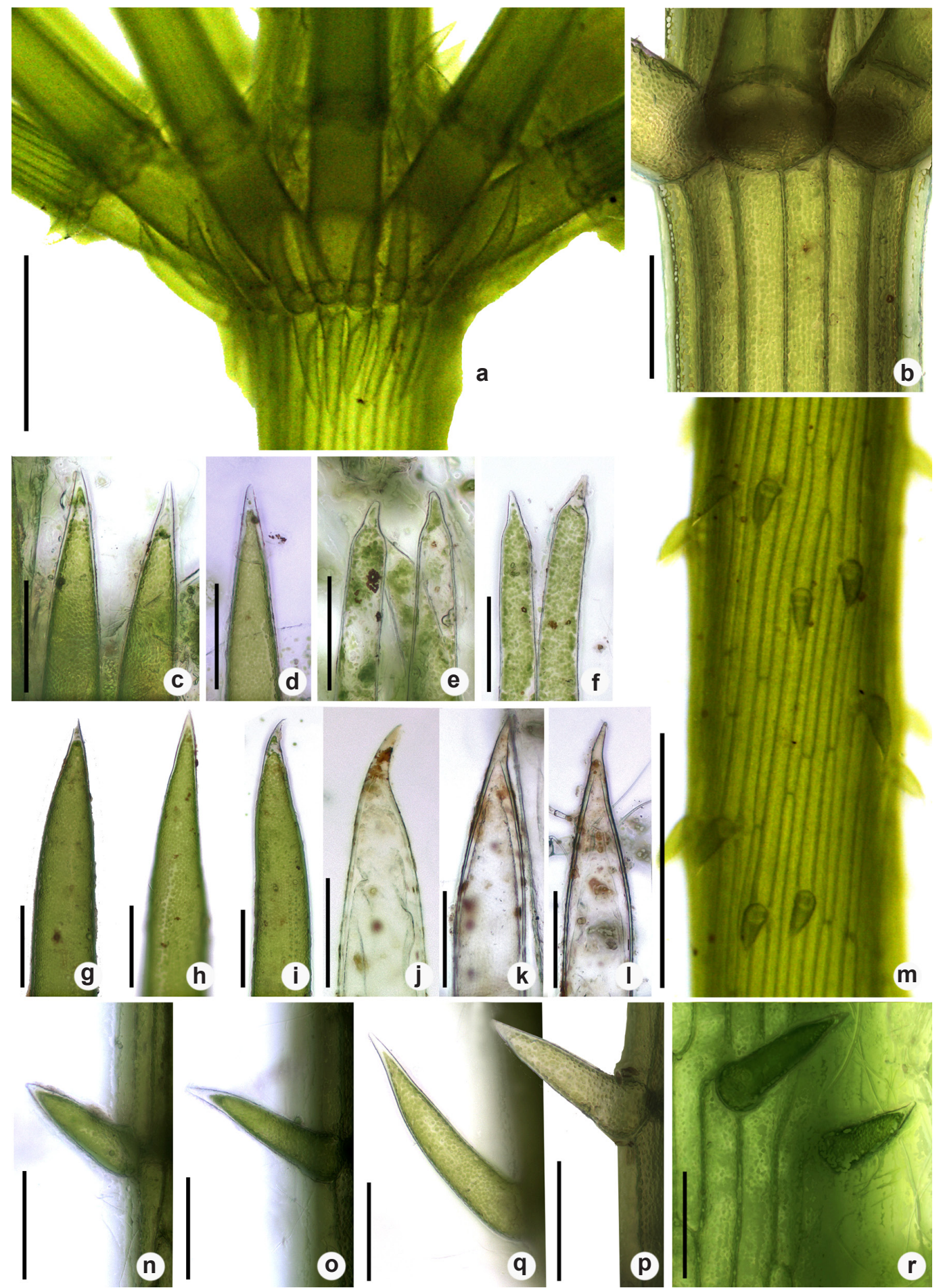

Figura 9 - a-r. Chara kenoyeri - a. detalhe de estipulóides diplostéfanos; b. detalhe do râmulo com córtex diplóstico; c,d. ápices acuminados dos estipulóides superiores; e,f. ápices acuminados dos estipulóides inferiores; g,h. ápices acuminados das brácteas; i,j. ápices acuminados das bractéolas; $\mathrm{k}, \mathrm{l}$. ápices acuminados das bracteletas; $\mathrm{m}$. detalhe do entrenó com córtex triplóstico - note células espiniformes; n-r. células espiniformes. Barras: a,m =0,5 mm; b-1,n-r $=120 \mu \mathrm{m}$.

Figure 9 - a-r. Chara kenoyeri - a. diplostephanous stipulodes detail; b. internode detail with diplostichous córtex; c,d. upper stipulodes acuminated apex; e,f. lower stipulodes acuminated apex; g,h. bract-cells acuminate apex; i,j. bracteoles acuminate apex; k,l. bractlets acuminate apex; $\mathrm{m}$. internode detail with triplostichous córtex - note spine cells; $\mathrm{n}-\mathrm{r}$. spine cells. Bars: a,m = 0,5 mm; b-1,n-r $=120 \mu \mathrm{m}$. 

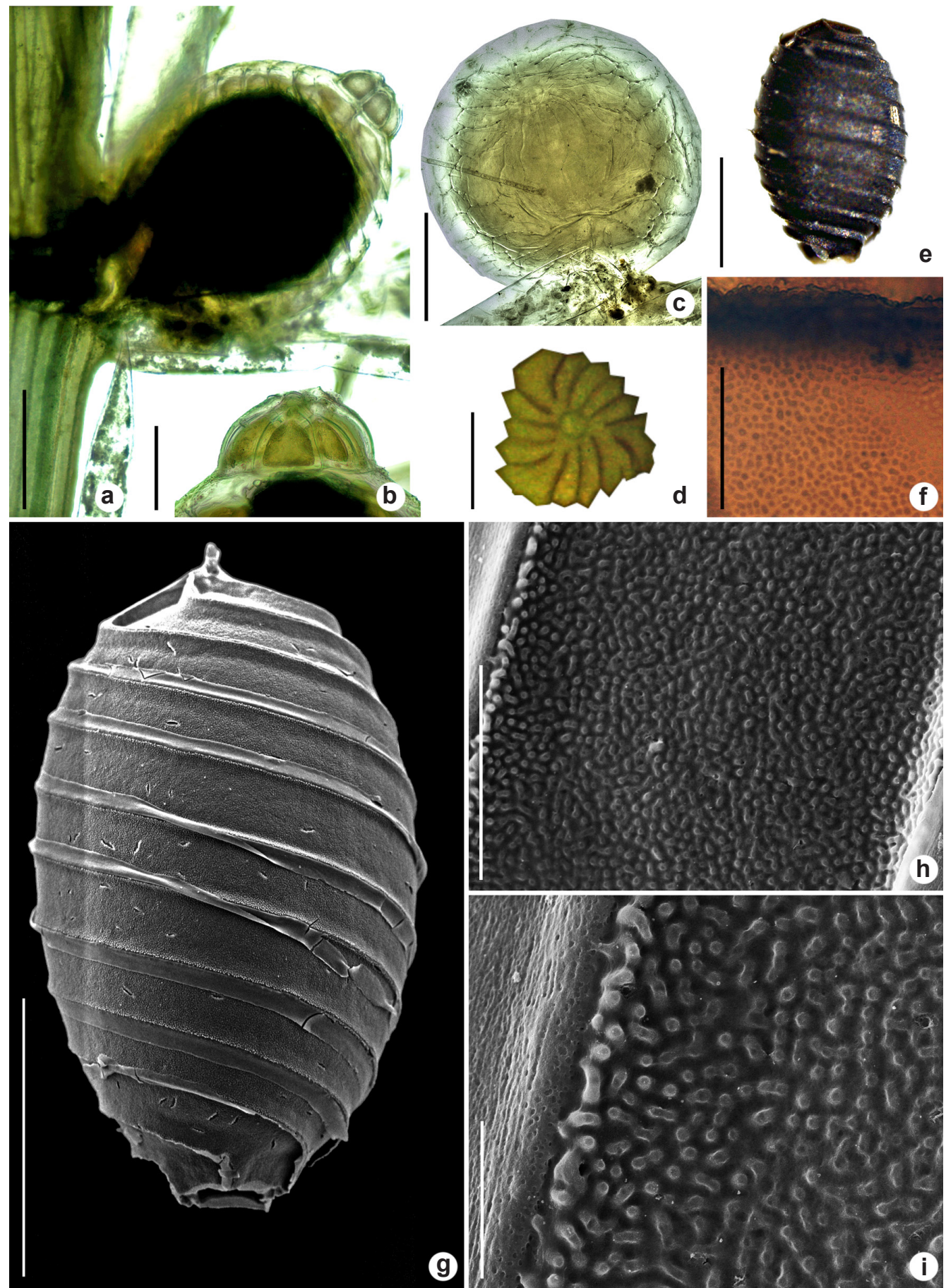

g

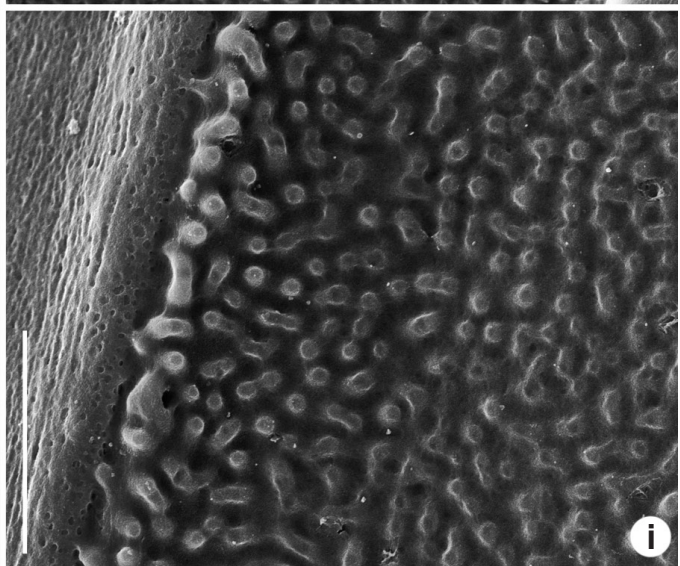

Figura 10 - a-i. Chara kenoyeri - a. núcula; b. detalhe de corônula convergente; c. glóbulo; d. detalhe do escudo triangular; e. oósporo visto em MO; f. detalhe da parede do oósporo granulada em MO; g. oósporo visto em MEV; h. parede do oósporo granulada em MEV - note grânulos densamente condensados; i. detalhe das projeções granulares, geralmente 2-3 unidas em MEV - note borda expandida rugosa possuindo perfurações. Barras: a,c,e,g = $300 \mu \mathrm{m}$; $\mathrm{b}, \mathrm{d}=120 \mu \mathrm{m} ; \mathrm{f}, \mathrm{h}=30 \mu \mathrm{m} ; \mathrm{i}=10 \mu \mathrm{m}$.

Figure 10 - a-i. Chara kenoyeri - a. oogonium; b. convergent coronula detail; c. antheridium; d. triangular scute; e. oospore in LM; f. granulate oospore wall detail in LM; g. oospore in SEM; h. granulate oospore wall in SEM - note densely condensed granules; i. granular projections detail, commonly $2-3$ joined in MEV - note roughed ribbon with perforations. Bars: a,c,e,g $=300 \mu \mathrm{m} ; \mathrm{b}, \mathrm{d}=120$ $\mu \mathrm{m} ; \mathrm{f}, \mathrm{h}=30 \mu \mathrm{m} ; \mathrm{i}=10 \mu \mathrm{m}$. 
$\mu \mathrm{m}$ diâm.; estipulóides diplostéfanos, superiores cobrindo os segmentos basais, 2 por râmulo, opostos a eles, ápices acuminados, superiores 349-578 $\mu \mathrm{m}$ compr., 30-59 $\mu \mathrm{m}$ diâm, inferiores

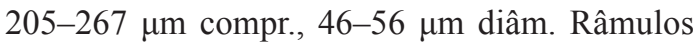
verticilados monomórficos, 11-12 por verticilo, 1,1-2,1 cm compr., 275-339 $\mu \mathrm{m}$ diâm.; segmentos 10-11, intercalares 9-10 corticados; segmento basal ecorticado 371-449 $\mu \mathrm{m}$ compr., 191-233 $\mu \mathrm{m}$ diâm.; segmentos apicais ecorticados rodeado por 5-6 brácteas; brácteas verticiladas $5-8$, com ápices acuminados, $81-167 \mu \mathrm{m}$ compr., 31-78 $\mu \mathrm{m}$ diâm.; bractéolas 2, 710-1.016 بm compr., 54-92 $\mu \mathrm{m}$ diâm.; bracteletas 798-948 $\mu \mathrm{m}$ compr., 67-75 $\mu \mathrm{m}$ diâm. Gametângios sejuntos, em nós diferentes de um mesmo râmulo verticilados, raramente conjuntos, $2^{\circ}-6^{\circ}$ nó basal; glóbulos alaranjados, 385-486 بm diâm., com 8 escudos triangulares; núculas 640-750 $\mu \mathrm{m}$ compr., 420-510 $\mu \mathrm{m}$ diâm., convoluções 10 , corônula 96-161 $\mu$ m compr., 117 $146 \mu \mathrm{m}$ diâm., com células de ápices divergentes. Morfologia do oósporo: Oósporo elipsoide, preto, 10-12 estrias, $630-720 \mu \mathrm{m}$ compr., $370-420 \mu \mathrm{m}$ de diâm., fossa 40-73 $\mu \mathrm{m}$ larg. Parede do oósporo em MO com padrão de ornamentação finamente granulado (Fig. 10g). Em MEV, em aumentos $\leq$ 200x a parede exibe discretas pontuações (Fig. $10 \mathrm{~h})$, e em aumentos superiores $(>2.000 \mathrm{x}$ ) revela padrão de ornamentação esponjoso, constituído por fibrilas anastomosadas espessas, formando espaços entre as anastomoses, lembrando poros (Fig. 10i). Estrias como mesmo padrão de ornamentação das paredes das fossas; presença de borda expandida. Habitat: Chara martiana foi encontrada crescendo na margem de tanque de fundo argiloso, associados a Nitella sp. e Chara kenoyeri M.Howe.

Variáveis abióticas da água $(\mathrm{n}=1)$ : Oxigênio dissolvido: $8 \mathrm{mg} . \mathrm{L}^{-1}, \mathrm{pH}$ : 7,55, sólidos totais dissolvidos: $0,11 \mathrm{ppt}$, condutividade elétrica: 0,23 mS.cm ${ }^{-1}$, temperatura: $31,1^{\circ} \mathrm{C}$.

Materiais examinados: Conceição do Jacuípe, região metropolitana de Feira de Santana, 19.II.2016, C.A. Ribeiro \& G.J.P. Ramos (HUEFS 225687).

Distribuição geográfica no Brasil: Piauí (Bicudo 1972,1974), Goiás (Bicudo 1972, 1974), São Paulo (Bicudo 1972, 1974; Picelli-Vicentim et al. 2004; Necchi-Junior. et al. 1995; Necchi-Junior. et al. 1997; Necchi-Junior. et al. 2000; Vieira-Junior. et al.2003), Mato Grosso (Bueno et al. 2009), Mato Grosso do Sul (Bueno et al. 2009), Paraná (Bueno et al. 2011), Rio Grande do Sul (Prado 2003; Bueno et al. 2011), Bahia (presente estudo).
Os espécimes ora analisados foram facilmente separados dos demais táxons identificados na RMS e RMFS por possuírem gametângios sejuntos, ausentes no nó basal e alternados nos nós dos râmulos verticilados.

Chara martiana é morfologicamente semelhante a $C$. guairensis R.M.T.Bicudo, mas esta difere por apresentar nó basal fértil e plantas de maior porte.

A análise da parede do oósporo em MO revelou ornamentação finamente granulada, como relatado na literatura (Bicudo 1972,1974; Prado 2003; Viera-Junior. et al. 2003; Picelli-Vicentim et al.2004). Entretanto, as análises em MEV revelaram que esta não apresenta padrão granulado, e sim esponjoso, constituído por fibrilas anastomosadas espessas, formando espaços entre as anastomoses; tais espaços dão a aparência de grânulos quando a parede é observada em MO.

Os espécimes estudados estão de acordo com as descrições e ilustrações apresentadas por Bicudo (1972, 1974), Prado (2003), Viera-Junior et al. (2003), Picelli-Vicentim et al. (2004) e Bueno et al. (2009, 2011).

O presente é o primeiro registro da ocorrência para a Bahia.

Chara rusbyana M.Howe, Field Museum of Natural History: Botanical series.4(6): 160, pl. 16. 1929.

Figs. $14 ; 15 ; 16$

Plantas dióicas, 22-46 cm compr., incrustação calcárea presente; caulóide 442-799(-834) $\mu \mathrm{m}$ diâm., entrenós $0,8-3(-4) \mathrm{cm}$ compr., córtex triplóstico; células espiniformes solitárias, 100 $387 \mu \mathrm{m}$ compr., 35-73 $\mu \mathrm{m}$ diâm.; estipulóides diplostéfanos, 2 por râmulo, opostos a eles, superiores 646-1.197 $\mu \mathrm{m}$ compr., 62-105 $\mu \mathrm{m}$ diâm., geralmente cobrindo o segmento basal dos râmulos, ápices acuminados ou arrendados, inferiores, 413-864 $\mu \mathrm{m}$ compr., 44-74 $\mu \mathrm{m}$ diâm, ápices acuminados. Râmulos verticilados monomórficos, 10-12, 1-3 cm compr., 302-381 $\mu \mathrm{m}$ diâm.; segmentos 8-10, intercalares 7-9 corticados, apicais ecorticados, rodeado por brácteas $4-5$; segmento basal ecorticado 400-699 $\mu \mathrm{m}$ compr., 177-342 $\mu \mathrm{m}$ diâm.; brácteas 4-9 verticiladas, 444-1.156 $\mu \mathrm{m}$ compr., 51-116 $\mu \mathrm{m}$ diâm., ápices acuminados-arredondados; bractéolas 2, geralmente mais longas do que as núculas, 792-1.316 $\mu \mathrm{m}$ compr., 52-100 $\mu \mathrm{m}$ diâm., ápices acuminados; bracteletas $607-1.222 \mu \mathrm{m}$ compr., 57-103 $\mu \mathrm{m}$ diâm, ápices acuminados. Gametângios em plantas separadas, situados nos $2^{\circ}$ ao $5^{\circ}$ nó basal; glóbulo 


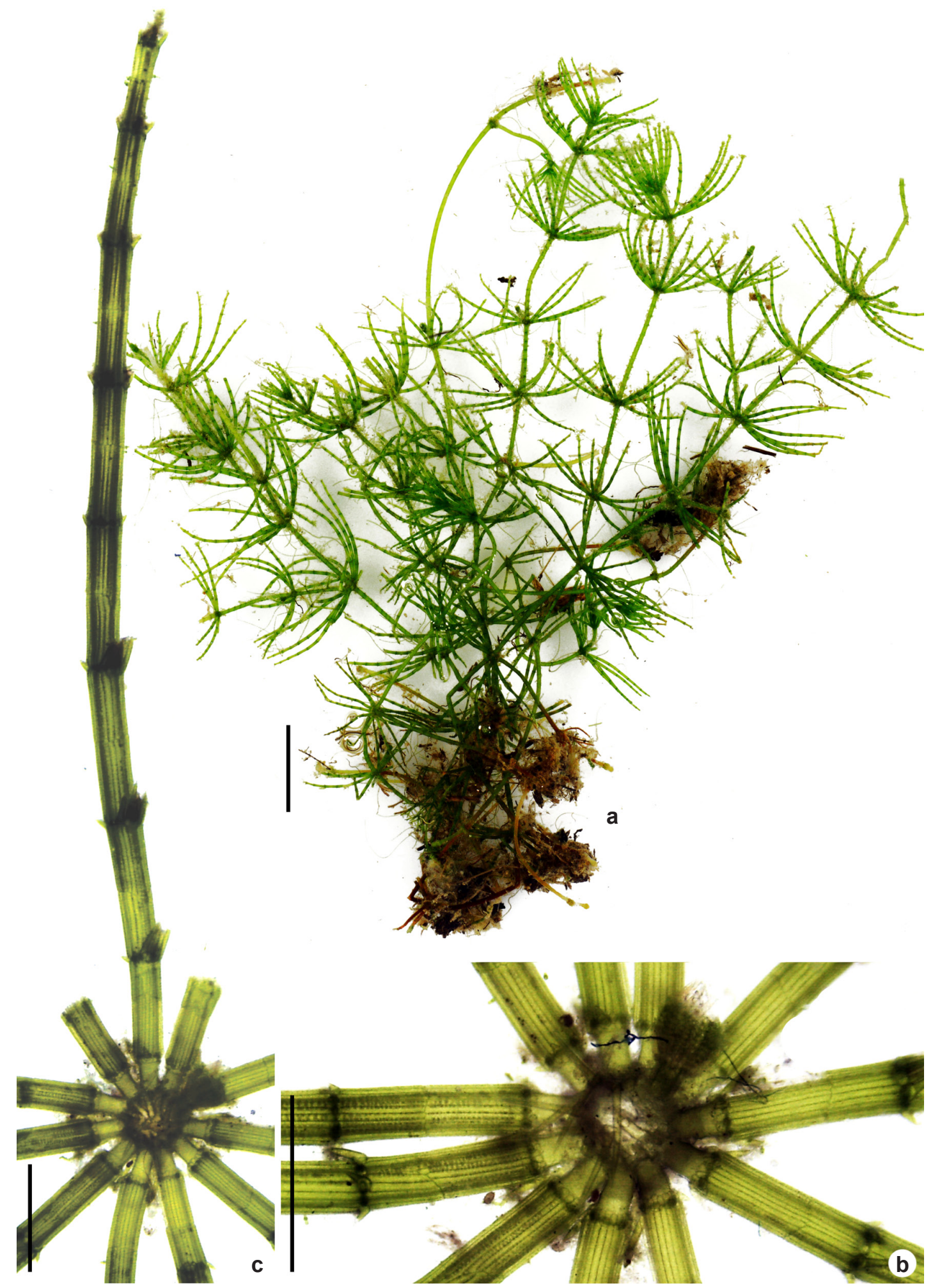

Figura 11 - a-c. Chara martiana - a. hábito; b. detalhe do verticilo estéril portando râmulos com segmentos basais ecorticados; c. detalhe do râmulo corticado 8-segmentados. Barras: $\mathrm{a}=1 \mathrm{~cm} ; \mathrm{b}, \mathrm{c}=1 \mathrm{~mm}$.

Figure 11 - a-c. Chara martiana - a. habit; b. esterile whorl detail showing ecorticated basal segments; c. 8-segmented corticated branchlet detail of the. Bars: $\mathrm{a}=1 \mathrm{~cm} ; \mathrm{b}, \mathrm{c}=1 \mathrm{~mm}$. 

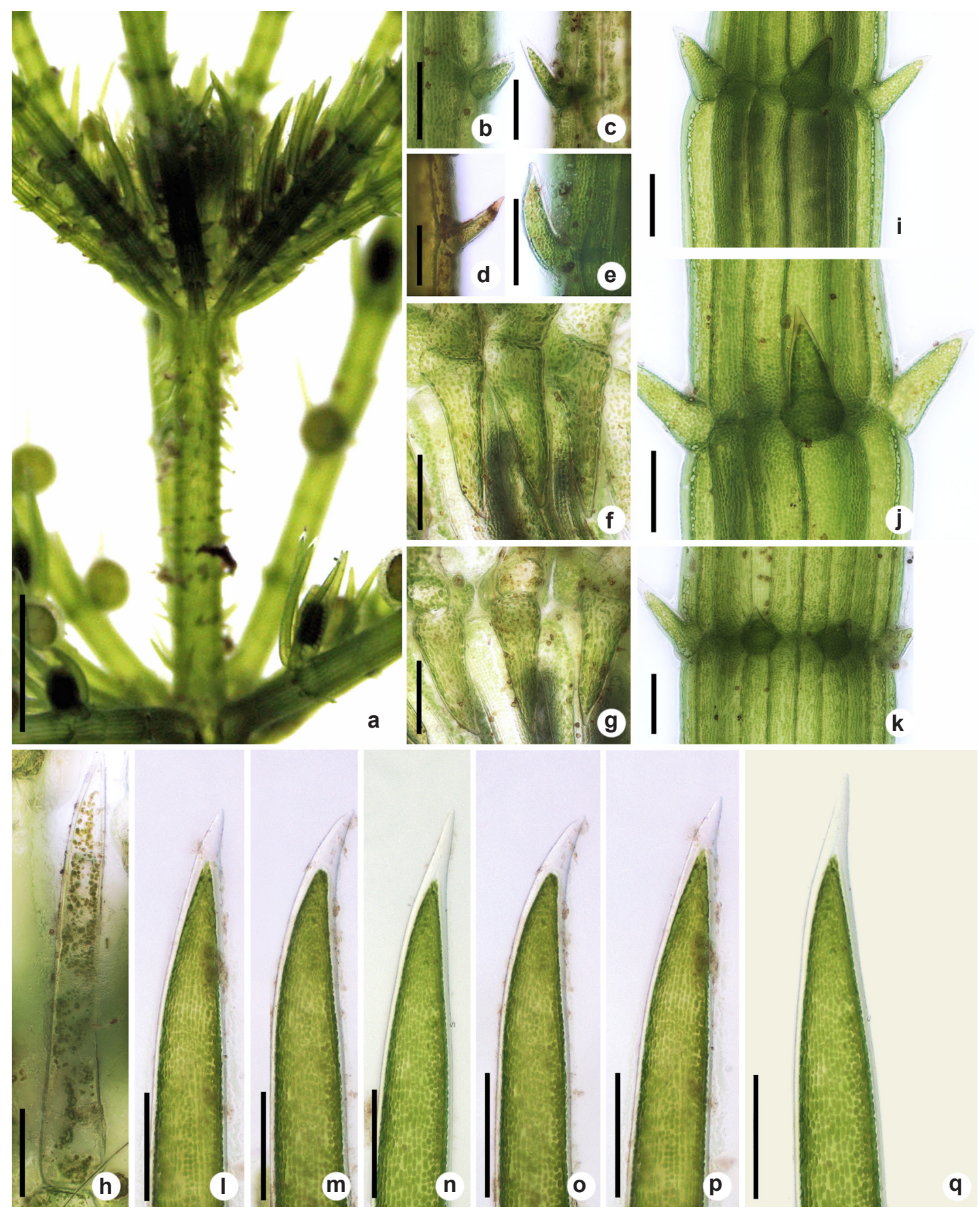

Figura 12 - a-q. Chara martiana - a. detalhe do entrenó com células espiniformes; b-e. células espiniformes com ápices acuminados; f,g. estipulóides inferiores com ápices acuminados; h. estipulóide superior com ápice acuminado; i-k. detalhe das brácteas em verticilo; 1-n. ápices acuminados das bracteletas; o-q. ápices acuminados das bractéolas. Barras: $\mathrm{a}=2 \mathrm{~mm} ; \mathrm{b}-\mathrm{q}=100 \mu \mathrm{m}$.

Figure 12 - a-q. Chara martiana - a. internode detail with spine cells; b-e. spine-cells with acuminate apex; f,g. lower stipulodes with acuminated apex; h. upper stipulodes acuminated apex; i-k. whorl bract-cell detail; l-n. bractlets acuminate apex; o-q. bracteoles acuminate apex. Bars: $\mathrm{a}=2 \mathrm{~mm} ; \mathrm{b}-\mathrm{q}=100 \mu \mathrm{m}$. 

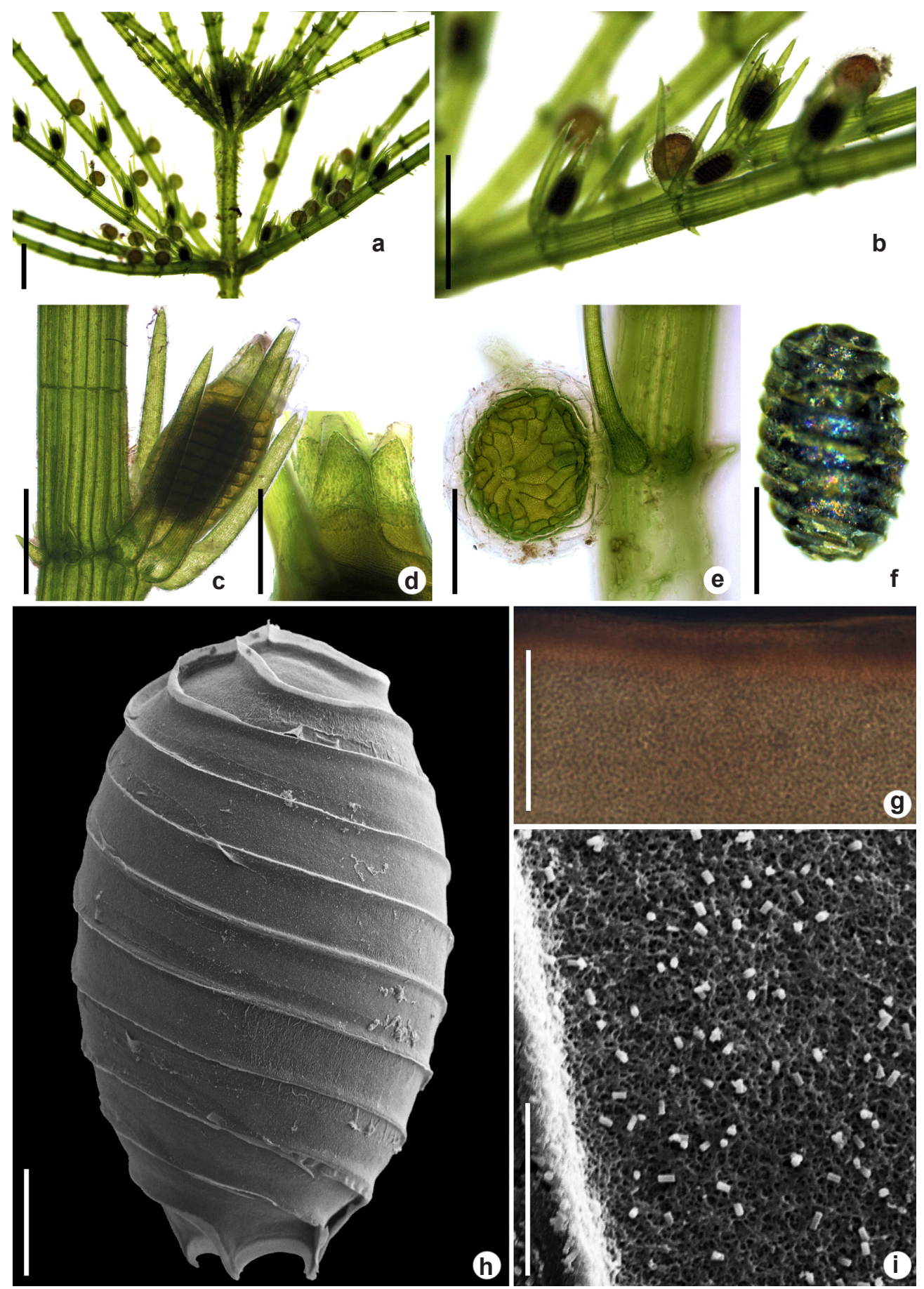

Figura 13 - a-i. Chara martiana - a. verticilo de râmulos férteis; b. detalhe do râmulo com nó basal estéril e gametângios conjuntos e sejuntos; c. núcula com bractéolas e bracteletas; d. detalhe da corônula divergente; e. glóbulo com escudos triangulares; f. oósporo visto em MO; g. detalhe da parede do oósporo finamente granulada em MO; h. oósporo visto em MEV; i. detalhe da parede esponjosa do oósporo em MEV. Barras: a,b = $1 \mathrm{~mm}$; c,d,f=300 $\mu \mathrm{m}$; e $=120 \mu \mathrm{m} ; \mathrm{g}=100 \mu \mathrm{m} ; \mathrm{h}, \mathrm{i}=10 \mu \mathrm{m}$.

Figure 13 - a-i. Chara martiana - a. fertile branchlet whorl; b. branchlet detail with sterile basal node and sejoined and conjoined gametanges; c. oogonium with bracteoles e bractlets; d. divergente coronula detail; e. antheridium with triangular scute; f. oospore in LM; g. finely granulate oospore wall detail in LM; h. oospore in SEM; i. spongy oospore wall detail in SEM. Bars: a,b=1 mm; c,d,f= $300 \mu \mathrm{m} ; \mathrm{e}=120 \mu \mathrm{m} ; \mathrm{g}=100 \mu \mathrm{m} ; \mathrm{h}, \mathrm{i}=10 \mu \mathrm{m}$. 
745-932 بm diâm., 8 escudos triangulares; núculas uma por nó, (615-)660-931 $\mu \mathrm{m}$ compr., 382-574 $\mu \mathrm{m}$ diâm., convoluções 10-11, corônula com ápices levemente divergentes, $123-182 \mu \mathrm{m}$ alt. e 142-203 $\mu \mathrm{m}$ diâm.

Morfologia do oósporo: Oósporo elipsoide, preto, incrustados com carbonato de cálcio, 10-12 estrias, 620-740 $\mu \mathrm{m}$ compr., 395-501 $\mu \mathrm{m}$ diâm., fossa 50 $70 \mu \mathrm{m}$ larg. Parede do oósporo em MO e MEV com padrão de ornamentação granulado (Fig. 16b,c). Em MEV, em aumentos $\leq 200 \mathrm{x}$ a parede exibe discretas pontuações (Fig. 16c); e em aumentos superiores $(>2.000 \mathrm{x})$ revela grânulos condensados, projetados, $0,9-1,5 \mu \mathrm{m}$ compr., $0,2-0,5 \mu \mathrm{m}$ diâm (Fig. 16e). Estrias seguindo o mesmo padrão de ornamentação da parede; presença de vestígios de rebordo expandido, possivelmente desgastada pelo processo de limpeza (Fig. 16d).

Habitat: Planta crescendo nas margens de lagoas e tanque de fundo areno-argiloso, associados a Utricularia sp., Salvinia sp., Nitella sp. e C. diaphana (Meyen) R.D.Wood.

Variáveis abióticas da água $(\mathrm{n}=3)$ : Oxigênio dissolvido: 9,23 $\pm 3,81 \mathrm{mg} . \mathrm{L}^{-1}, \mathrm{pH}: 8,19 \pm$ 0,95 , sólidos totais dissolvidos: $0,18 \pm 0,09 \mathrm{ppt}$, condutividade elétrica: $0,36 \pm 0,19 \mathrm{mS} \cdot \mathrm{cm}^{-1}$, temperatura: $28,1 \pm 1,14^{\circ} \mathrm{C}$.

Materiais examinados: Feira de Santana, região metropolitana de Feira de Santana, 13.X.2015, C.A. Ribeiro \& C.W.N. Moura (HUEFS 225678). São Gonçalo dos Campos, 22.I.2015, C.A. Ribeiro \& G.J.P. Ramos (HUEFS 225683). São Sebastião do Passé, região metropolitana de Salvador, 15.III.2016, C.A. Ribeiro \& G.J.P. Ramos (HUEFS 225709).

Distribuição geográfica no Brasil: Piauí (Bicudo 1972, 1974), Paraíba (Siqueira-Filho \& Bueno 2012; Sabino et al. 2015), Pernambuco (Bicudo 1972, 1974), Minas Gerais (Bicudo 1972, 1974), Mato Grosso (Bicudo 1972, 1974), São Paulo (Bicudo 1972, 1974; Picelli-Vicentim 1990; PicelliVicentim et al. 2004), Santa Catarina (Bicudo 1972, 1974; Bueno et al. 2011), Mato Grosso do Sul (Bueno et al. 1996; Bueno et al. 2009; Borges \& Necchi-Junior 2017), Paraná (Meurer \& Bueno 2012), Rio Grande do Sul (Prado 2003; Bueno et al. 2011), Bahia (presente estudo).

As populações de Chara rusbyana foram distintas das demais inventariadas neste estudo, pela presença de brácteas pequenas e pela dioicia. O táxon é morfologicamente próximo à $C$. kenoyeri, mas, esta difere pela presença de brácteas longas (1.232-2.676 $\mu \mathrm{m}$ compr.) e verticilos com 13-14 râmulos.
A parede do oósporo, quando observado em MO e MEV, apresentou padrão de ornamentação granulado, concordando com o descrito em MO por Bueno et al. (2009). Entretanto, dois outros padrões foram relatados em MO para plantas no Brasil: irregularmente reticulado (Prado 2003, para plantas do Rio Grande do Sul) e "homogêneo" (Bueno et al. 2011 para plantas do Rio Grande do Sul; Meurer \& Bueno 2012 para plantas no Paraná).

John et al. (1990), analisando a parede do oósporo de espécimes de C. rusbyana da Argentina, descreveram este como pustuloso. Entretanto, a ilustração apresentada pelos autores só destaca uma elevação pustular, não sendo possível observar com clareza a ornamentação desta. Diante disso, salienta-se a necessidade da análise do oósporo do material tipo para confirmar a padrão de ornamentação da espécie.

Aparentemente a espécie é restrita a América do Sul (Proctor et al. 1971), com amplo registro na literatura brasileira (Bicudo 1972; Bueno et al. 1996; Prado 2003; PicelliVicentim et al. 2004; Bueno et al. 2009; Meurer \& Bueno 2012; Bueno et al. 2011). As descrições, ilustrações e variações morfométricas registradas no presente trabalho estão de acordo com as descritas para as plantas brasileiras.

Esse é primeiro registro da ocorrência da espécie para a Bahia.

Chara zeylanica Klein ex Willd., Mémoires de l'Academie Royale de Berlin. 1803, 86. 1805.

Figs. $17 ; 18 ; 19$

Plantas monóicas, 10-65 cm compr., ásperas ao toque, incrustação calcárea forte; caulóide 406-970 $\mu \mathrm{m}$ diâm.; entrenós 0,9-4,9 cm compr., córtex triplóstico; células espiniformes 103-955 $\mu \mathrm{m}$ compr., $28-108 \mu \mathrm{m}$ diâm., ápices acuminados; estipulóides diplostéfanos, dois por râmulo verticilado, opostos a eles, ápices acuminados,

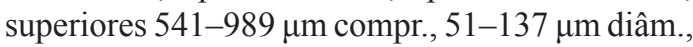
estipulóides inferiores 147-625 $\mu \mathrm{m}$ compr., 44-101 $\mu \mathrm{m}$ diâm. Râmulos verticilados monomórficos, 10-14, 0,7-2,5 cm compr., 159-525 $\mu \mathrm{m}$ diâm.; segmentos 6-11; intercalares 5-10 corticados; apicais ecorticados, acuminados, mais longos que as brácteas que os cercam, rodeados por 4-6 brácteas; segmento basal ecorticado 303-980 $\mu \mathrm{m}$ compr., 117-402 $\mu \mathrm{m}$ diâm.; brácteas $5-8$ verticiladas, 189-839 $\mu \mathrm{m}$ compr., (46-)63-132 $\mu \mathrm{m}$ diâm.; bractéolas 2, geralmente mais longas do que as núculas maduras, 807-1.395(-1.524) 


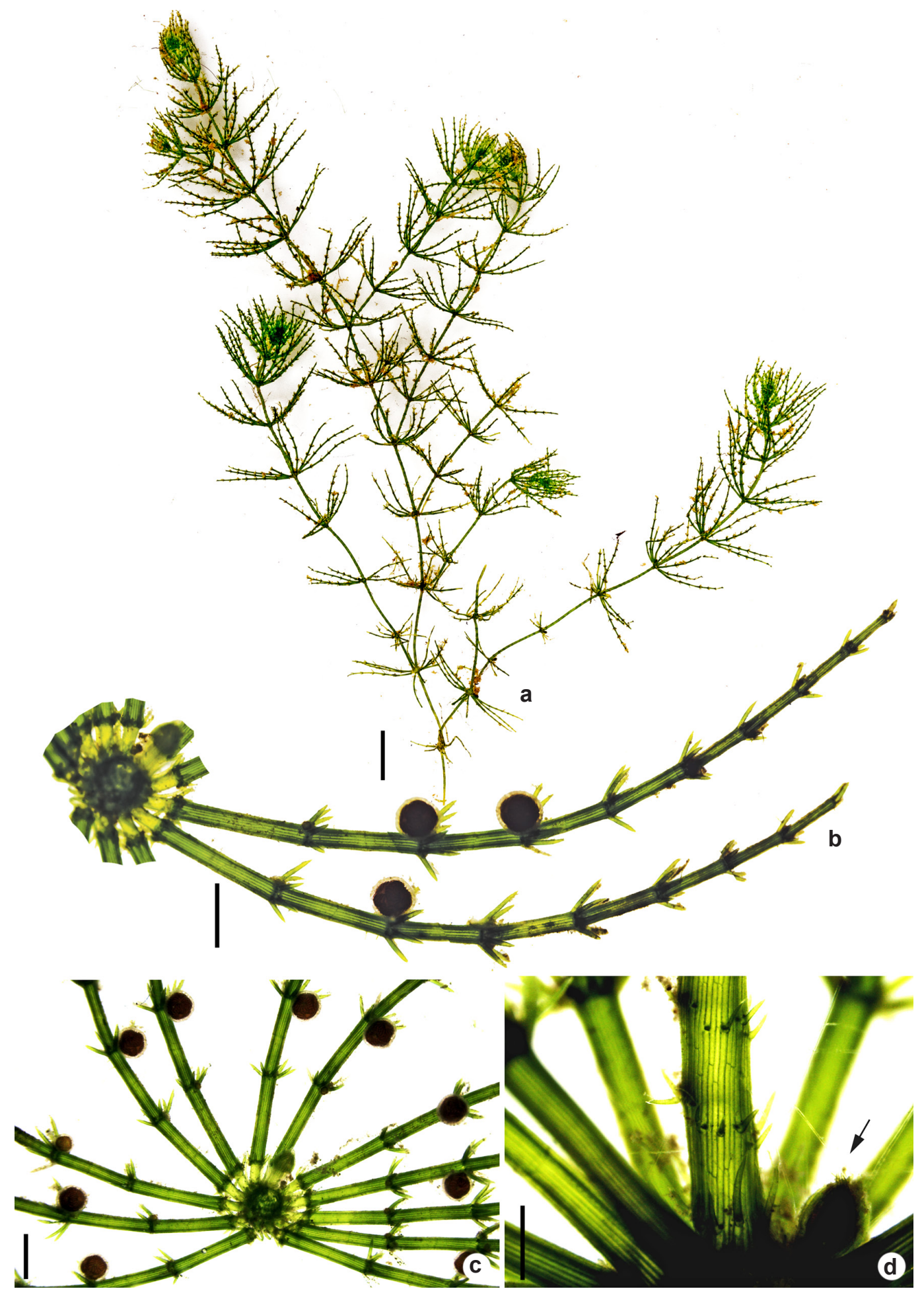

Figura 14 - a-d. Chara rusbyana - a. hábito; b. râmulo fértil 8-segmentado; c. verticilo com râmulos férteis, note glóbulos e segmentos basais ecorticados; d. detalhe do entrenó com córtex triplóstico e células espiniformes, note saída de verticilo de râmulos jovem (seta). Barras: $a=1 \mathrm{~cm} ; \mathrm{b}, \mathrm{c}=1 \mathrm{~mm} ; \mathrm{d}=0,5 \mathrm{~mm}$.

Figure 14 -a-d. Chara rusbyana - a. habit; b. 8-segmented fertile branchlet; c. fertile branchlet whorl, note antheridium and ecorticated basal segments; d. internode detail with triplousthicous cortex and spine cell, note young branchlet whorl (arrow). Bars: $\mathrm{a}=1 \mathrm{~cm} ; \mathrm{b}, \mathrm{c}$ $=1 \mathrm{~mm} ; \mathrm{d}=0,5 \mathrm{~mm}$. 

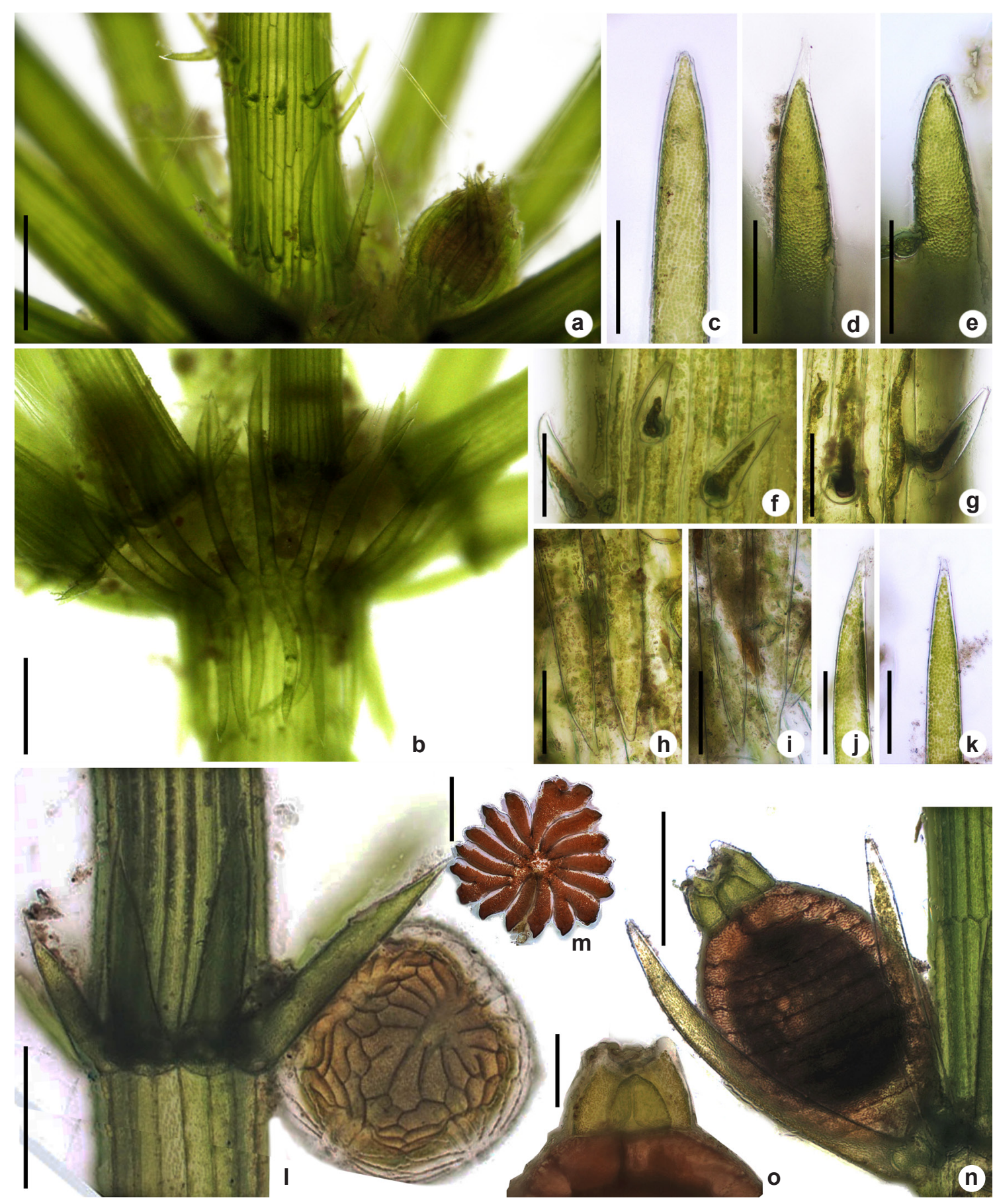

Figura 15 - a-o. Chara rusbyana - a. células espiniformes distribuídas ao longo do entrenó; b. detalhe dos estipulóides diplostéfanos; c-e. ápices acuminados-arredondados das brácteas; f,g. células espiniformes com ápices acuminadosarredondados; h,i. ápices acuminados de estipulódios inferiores; j,k. ápices acuminados de estipulódio superior; 1. glóbulo; $\mathrm{m}$. escudo triangular; $\mathrm{n}$. núcula; o. detalhe da corônula levemente divergente. Barras: $\mathrm{a}, \mathrm{b}=0,5 \mathrm{~mm} ; \mathrm{c}-\mathrm{k}, \mathrm{o}$ $=120 \mu \mathrm{m} ; 1-\mathrm{n}=250 \mu \mathrm{m}$.

Figure 15 - a-o. Chara rusbyana - a. spine cells distributed along of the internode; b. diplostephanous stipulodes detail; c-e. bractcells acuminated-rounded apex; f,g. spine cells with acuminated-rounded apex; h,i. lower stipulodes with acuminated apex; j,k. upper stipulodes acuminated apex; 1 . antheridium; $\mathrm{m}$. triangular scute; $\mathrm{n}$. oogonium; o. slightly divergent coronula detail. $\mathrm{Bars:} \mathrm{a}, \mathrm{b}=0,5 \mathrm{~mm}$; $\mathrm{c}-\mathrm{k}, \mathrm{o}=120 \mu \mathrm{m} ; \mathrm{l}-\mathrm{n}=250 \mu \mathrm{m}$. 


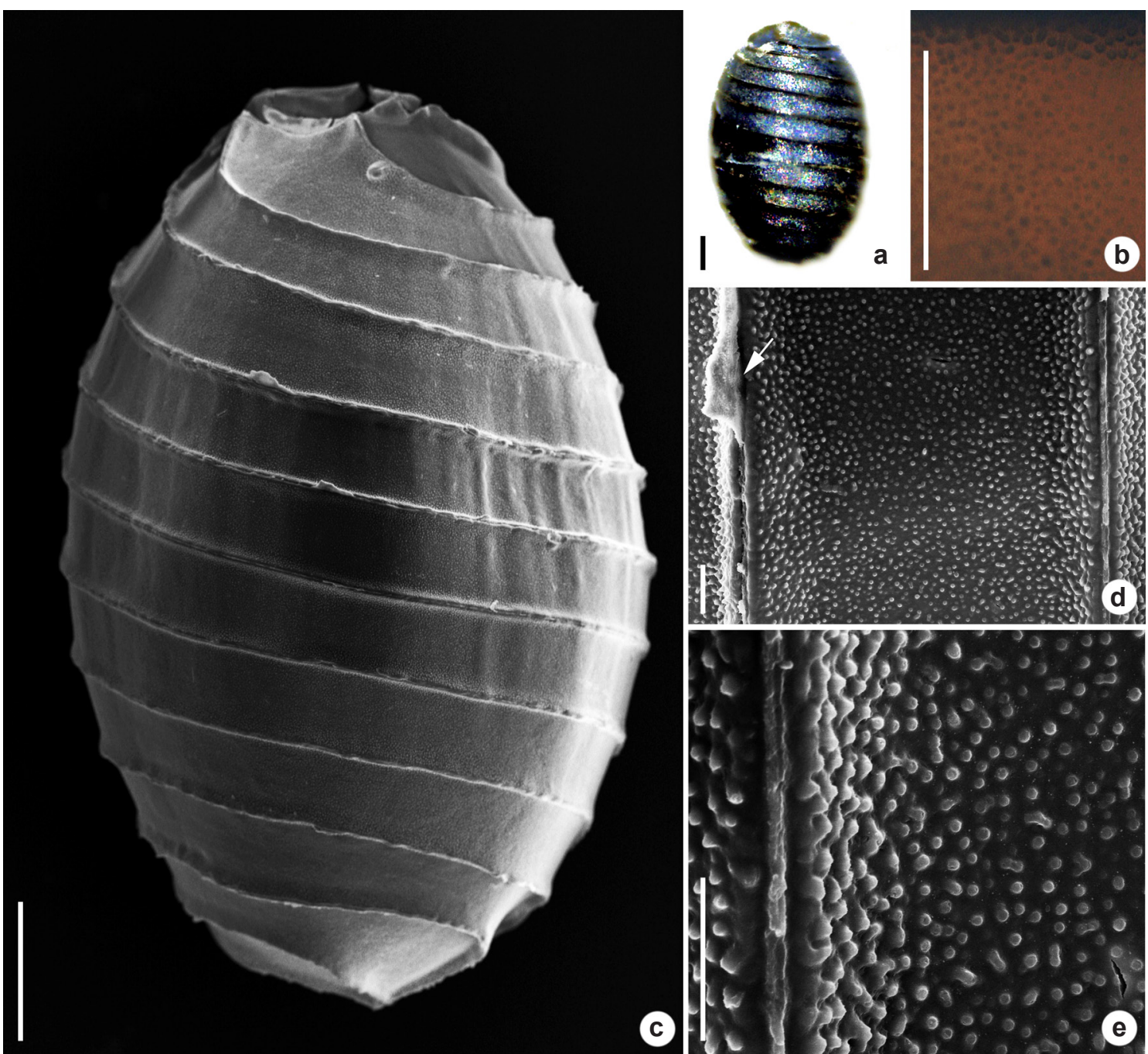

Figura 16 - a-e. Chara rusbyana - a. oósporo visto em MO; b. detalhe da parede do oósporo granulada em MO; c. oósporo visto em MEV; d. detalhe da fossa do oósporo em MEV, note vestígios de rebordo expandido (seta); e. parede do oósporo granulada com projeções granulares proeminentes em MEV. Barras: $\mathrm{a}, \mathrm{b}=100 \mu \mathrm{m} ; \mathrm{c}, \mathrm{d}=10 \mu \mathrm{m}$. Figure 16 - a-e. Chara rusbyana - a. oospore in LM; b. granulate oospore wall detail in LM; c. oospore in SEM; d. oospore fossa detail in SEM, note traces of the ribbon (arrow); e. granulate oospore wall with granules projected in SEM. Bars: a,b $=100 \mu \mathrm{m} ; \mathrm{c}, \mathrm{d}=10 \mu \mathrm{m}$.

$\mu \mathrm{m}$ compr., 51-123 $\mu \mathrm{m}$ diâm.; bracteletas ausentes. Gametângios conjuntos, do $1^{\circ}$ ao $3^{\circ}$ nó basal; glóbulos alaranjados 252-548 $\mu \mathrm{m}$ diâm., com 4 escudos losangulares; núculas $568-1.036$ (-1.162) $\mu \mathrm{m}$ compr., 209-657 $\mu \mathrm{m}$ diâm.; 10-13 convulações, corônula 55-258 $\mu \mathrm{m}$ alt. e 83-294 $\mu \mathrm{m}$ larg., divergente.

Morfologia do oósporo: Oósporo elipsoide, preto, 10-11 estrias, 661-700 $\mu \mathrm{m}$ compr., 387-545 $\mu \mathrm{m}$ diâm., fossa 45-90 $\mu \mathrm{m}$ larg. Parede do oósporo em MO apresentando padrão finamente granulado (Fig. 19b). Em MEV, em aumentos $\leq 300 \mathrm{x}$ a parede exibe discretas granulações (Fig. 19c), e em aumentos superiores $(>2.000 \mathrm{x})$ apresenta padrão de ornamentação pustuloso (Fig. 19d,e), com elevações de formato irregular, tamanho variado $(0,1-0,4 \mu \mathrm{m}$ diâm $)$, com perfuração na porção central (Fig. 19f). Estrias seguindo o mesmo padrão de ornamentação das paredes das fossas; presença de borda expandida discreta.

Habitat: Cresce nas margens de lagoas de fundo arenoso e de tanques de fundo areno-argiloso, associados a Gramineae, Cyperaceae, Elodea sp., Chara kenoyeri M.Howe e Nitella sp. 


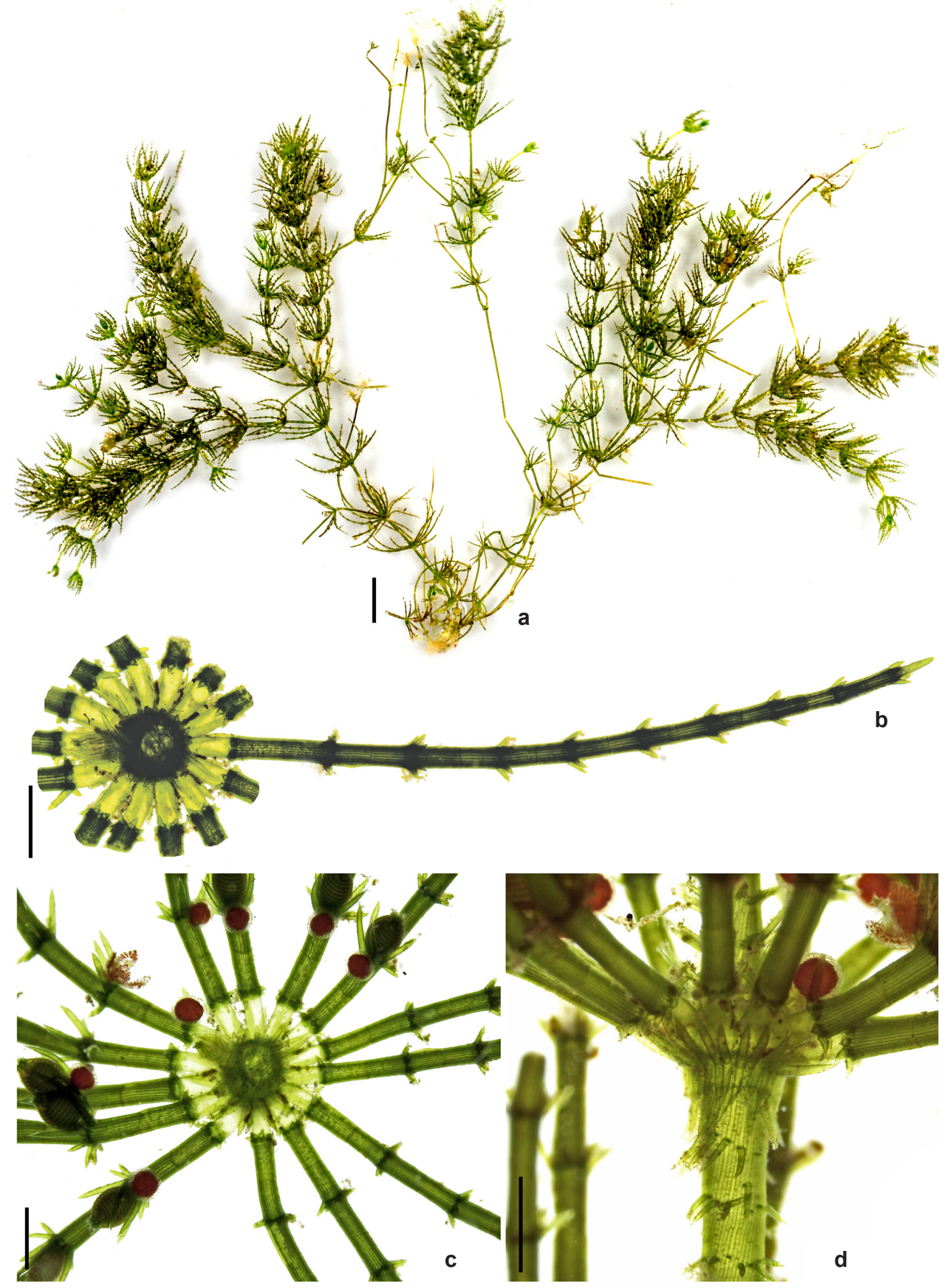

Figura 17 -a-d. Chara zeylanica - a. hábito; b. râmulo 11-segmentado, note segmento basal e apical ecorticado; c. verticilo com râmulos férteis; d. detalhe do entrenó corticado com células espiniformes. Barras: $\mathrm{a}=1 \mathrm{~cm} ; \mathrm{b}-\mathrm{d}=1 \mathrm{~mm}$. Figure 17 - a-d. Chara zeylanica - a. habit; b. 11-segmented fertile branchlet, note ecorticated basal and apical segment; c. fertile branchlet whorl; d. corticated internode detail with spine cells. Bars: $\mathrm{a}=1 \mathrm{~cm} ; \mathrm{b}-\mathrm{d}=1 \mathrm{~mm}$. 


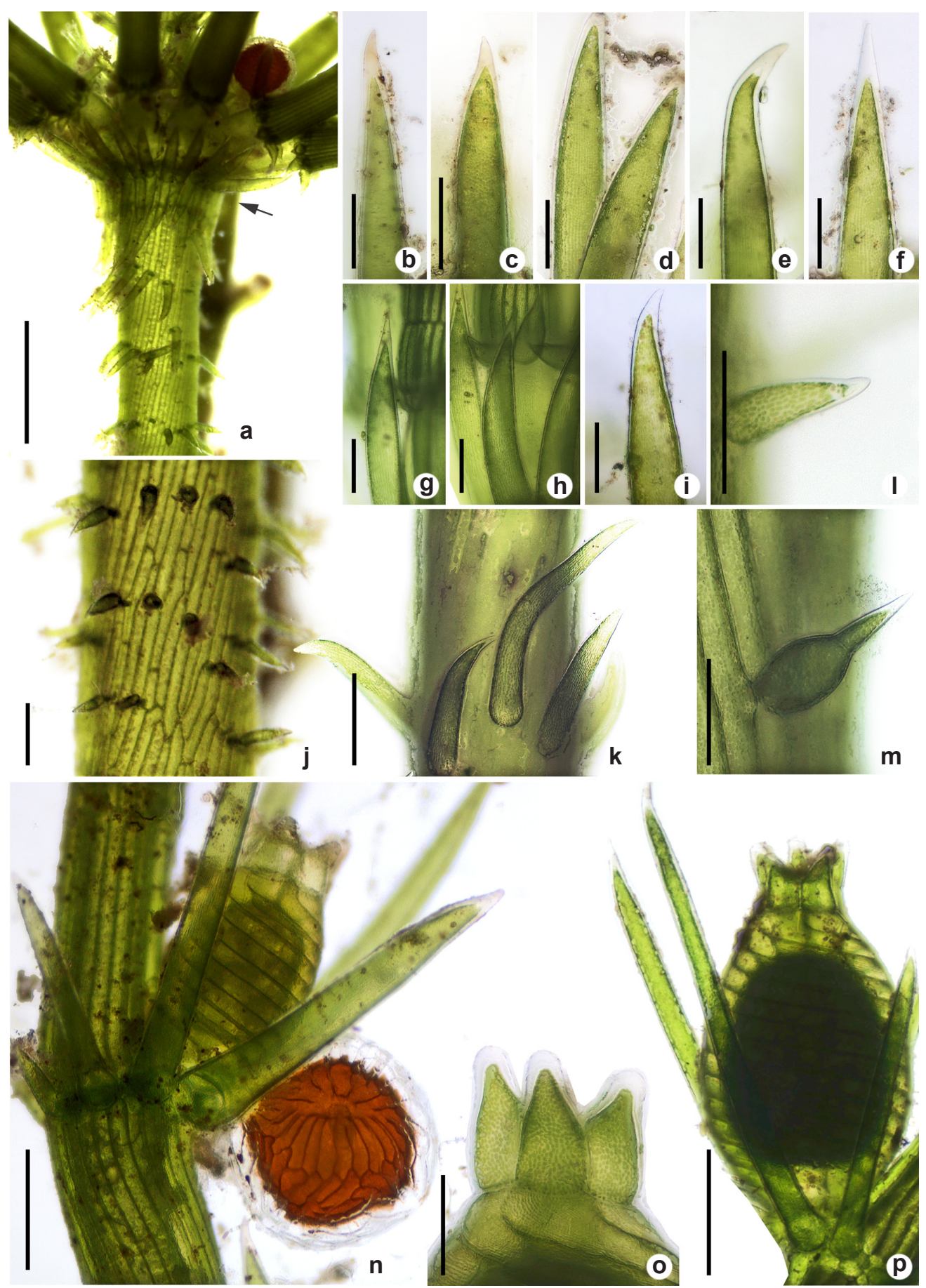

Figura 18 - a-p. Chara zeylanica - a. detalhe do entrenó e nó - note estipulóides diplóstico (seta); b-d. ápices acuminados-arredondados das brácteas; e,f. ápices acuminados-arredondados das bractéolas; g,h. ápices acuminados dos estipulódios superiores; i. ápices acuminados de estipulódios inferiores; j. detalhe do entrenó com córtex triplóstico e células espiniformes; k-m. células espiniformes; $n$. gametângios conjuntos, note glóbulo com escudos losangulares; o. corônula; p. núcula. Barras: $\mathrm{a}=1 \mathrm{~mm} ; \mathrm{b}-\mathrm{i}, 1, \mathrm{~m}, \mathrm{p}=120 \mu \mathrm{m} ; \mathrm{j}, \mathrm{k}=200 \mu \mathrm{m} ; \mathrm{n}, \mathrm{p}=300 \mu \mathrm{m}$.

Figure 18 - a-p. Chara zeylanica - a. internode and node detail, note diplostephanous stipulodes (arrow); b-d. bract-cells acuminatedrounded apex; e,f. bracteoles acuminated-rounded apex; g,h. upper stipulodes acuminated apex; i. lower stipulodes acuminated apex; j. internode detail with triplosthicous córtex and spine cells; $\mathrm{k}-\mathrm{m}$. spine cells; $\mathrm{n}$. conjoined gametanges, note antheridium with lozangeshape scute; o. coronula; $\mathrm{p}$. oogonium. Bars: $\mathrm{a}=1 \mathrm{~mm} ; \mathrm{b}-\mathrm{i}, 1, \mathrm{~m}, \mathrm{p}=120 \mu \mathrm{m} ; \mathrm{j}, \mathrm{k}=200 \mu \mathrm{m} ; \mathrm{n}, \mathrm{p}=300 \mu \mathrm{m}$. 


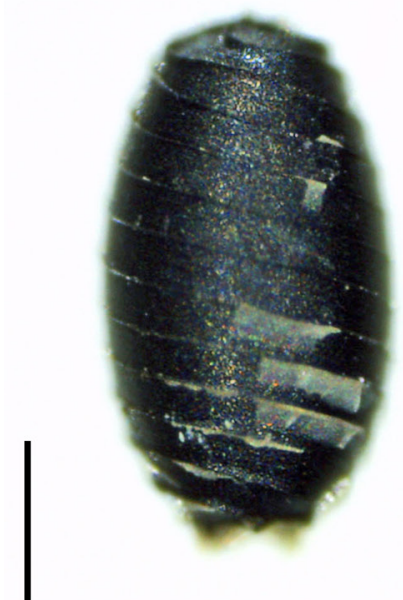

a
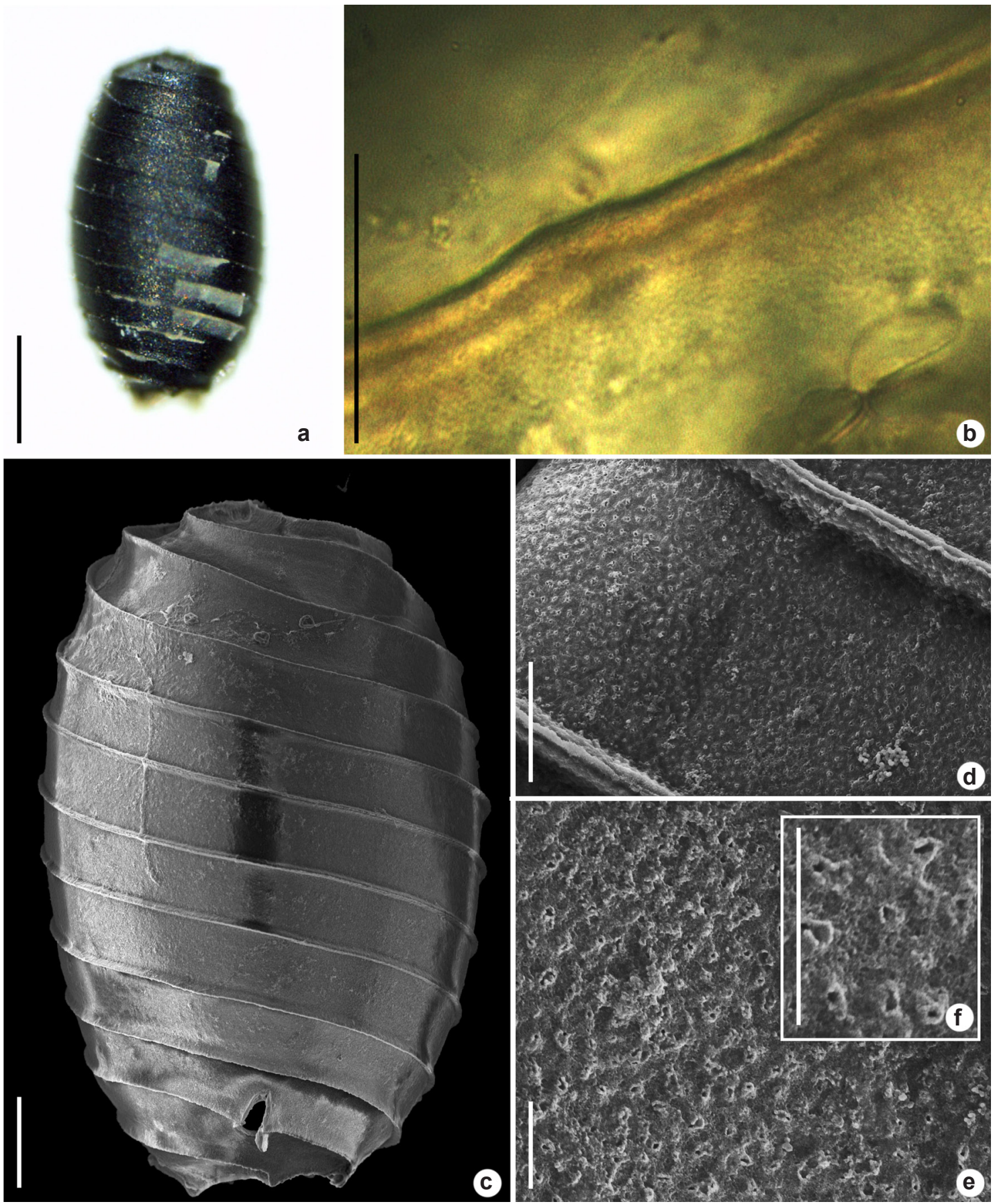

Figura 19 - a-f. Chara zeylanica - a. oósporo visto em MO; b. detalhe da parede do oósporo finamente granulada visto em MO; c. oósporo visto em MEV, parede exibindo discretas granulações; d. parede pustulosa do oósporo em MEV; e. detalhe das pústulas em MEV; f. detalhe das perfurações na porção central da pústula. Barras: a = $200 \mu \mathrm{m}$; $\mathrm{b}=30 \mu \mathrm{m} ; \mathrm{c}=50 \mu \mathrm{m} ; \mathrm{d}-\mathrm{f}=10 \mu \mathrm{m}$.

Figure 19 - a-f. Chara zeylanica - a. oospore in LM; b. finely granulate oospore wall detail in LM; c. oospore in SEM, wall showing discreet grains; d. pustulate oospore wall in SEM; e. pustule detail in SEM; f. detail of the perforations in the central portion of the pustule. Bars: $\mathrm{a}=200 \mu \mathrm{m} ; \mathrm{b}=30 \mu \mathrm{m} ; \mathrm{c}=50 \mu \mathrm{m} ; \mathrm{d}-\mathrm{f}=10 \mu \mathrm{m}$. 
Variáveis abióticas da água $(\mathrm{n}=13)$ : Oxigênio dissolvido: 7,35 $\pm 3,82 \mathrm{mg} . \mathrm{L}^{-1}, \mathrm{pH}: 8,40 \pm$ 0,81 , sólidos totais dissolvidos: $0,25 \pm 0,26 \mathrm{ppt}$, condutividade elétrica: $0,51 \pm 0,53 \mathrm{mS} \cdot \mathrm{cm}^{-1}$, temperatura: $30,5 \pm 1,82^{\circ} \mathrm{C}$.

Materiais examinados: Anguera, região metropolitana de Feira de Santana, 24.II.2016, C.A. Ribeiro \& G.J.P. Ramos (HUEFS 225694, HUEFS 225695, HUEFS 225696). Camaçari, região metropolitana de Salvador, 2.X.2015, C.A. Ribeiro et al. (HUEFS 225702, HUEFS 225703, HUEFS 225706). Conceição do Jacuípe, 19.II.2016, C.A. Ribeiro \& G.J.P. Ramos (HUEFS 225689). Salvador, 18.IX.2015, C.A. Ribeiro \& G.J.P. Ramos (HUEFS 225700). São Francisco do Conde, 8.IX.2014, M.A. Santos et al. (HUEFS 225659); 1.IV.2016, C.A. Ribeiro \& G.J.P. Ramos (HUEFS 225712). São Sebastião do Passé, 8.IX.2014, M.A. Santos et al. (HUEFS 225655). Serra Preta, 24.II.2016, C.A. Ribeiro \& G.J.P. Ramos (HUEFS 225697); 27.XI.2015, C.A. Ribeiro \& G.J.P. Ramos (HUEFS 225707).

Distribuição no Brasil: Roraima (Menezes et al. 2015), Pará, Rio Grande de Norte (Henry-Silva et al. 2013), Pernambuco (Siqueira-Filho \& Bueno 2012), Espírito Santo (Bicudo1972, 1974), Mato Grosso (Menezes et al. 2015), Mato Grosso do Sul (Menezes et al. 2015), Rio Grande do Sul (Astorino 1983; Bicudo 1972,1974), Sul do Brasil, local não especificado (Proctor et al. 1971), Bahia (presente estudo).

Chara zeylanica assemelha-se morfologicamente à $C$. diaphana (Meyen) R.D.Wood, mas esta difere por possuir segmentos intercalares dos râmulos verticilados parcialmente ecorticados.

Astorino (1983), estudando plantas do Rio Grande do Sul, relatou espécimes aparentemente dióicos com acentuada protandria, tendo encontrado plantas portando núculas e com cicatrizes dos glóbulos decíduos. Tal característica não foi observada nas populações estudadas.

Análises da parede do oósporo em MO revelaram padrão finamente granulado, concordando com o registrado por Bicudo (1972, para populações do Espirito Santo e Rio Grande do Sul) e por Astorino (1983, para plantas do Rio Grande do Sul). Por outro lado, as observações em MEV revelaram um padrão distinto, com parede do oósporo portando pústulas.

O padrão encontrado nos espécimes analisados em MEV difere daqueles relatados por Mandal \& Ray (2004) e Chalotra et al. (2013) para espécimes de C. zeylanica da Índia que, respectivamente, descreveram padrão granulado $\mathrm{e}$ escabroso, e por Casanova (2005), que descreveu padrão granulado para plantas da Austrália. Diante disso, salienta-se a necessidade da análise do oósporo do material tipo para confirmar a padrão de ornamentação da espécie.

O padrão de ornamentação dos oósporos de C. zeylanica analisados, assemelha-se ao descrito por Ray et al. (2001) e Mandal et al. (2002) para exemplares de C. vulgaris, embora este seja distinto por apresentar pústulas mais proeminentes. Semelhanças no padrão de ornamentação da parede do oósporo foram observadas ainda entre as populações de C. zeylanica e $C$. diaphana presentemente estudadas.

Os espécimes estudados estão de acordo com as descrições e ilustrações registradas por Bicudo (1972, 1974), Astorino (1983) e Bueno et al. (2011).

Esse é primeiro registro da ocorrência da espécie para a Bahia.

A partir desse estudo foi possível registrar cinco novas adições para a ficoflora da Bahia (C.diaphana, C. kenoyeri, C. martiana, C. rusbyana, $C$. zeylanica) e confirmar a ocorrência de $C$. hydroptis, citada anteriormente por Braun \& Nordstedt (1882 como C. hydropitys var. genuina A.Braun) e Bicudo (1972, 1974 como C. fibrosa var. hydropitys f. hydropitys R.D.Wood). As espécies C. fibrosa C.Agardh ex Bruzelius emend. R.D.Wood, C. formosa C.B.Rob. e C. vulgaris L. emend. R.D.Wood anteriormente registradas por Bicudo $(1972,1974)$ para o estado, não foram encontrados na área estudada.

Comparando o número de táxons de Chara inventariados com os citados em outros levantamentos realizados no Brasil constatouse que este foi próximo daqueles obtidos por Picelli-Vicentim et al. (2004) para o estado de São Paulo, Prado (2003) no Rio Grande do Sul e Meurer \& Bueno (2012) no Paraná, que relataram respectivamente, seis, nove e quatro táxons, e maior que os relatados por Astorino (1983) para o Rio Grande do Sul e por Bueno et al. (1996) e Vieira Junior et al. (2003), para o Mato Grosso do Sul e para ambientes lóticos de São Paulo, respectivamente. Trabalhos mais amplos foram desenvolvidos por Bicudo (1972), sendo este o maior e mais importante trabalho de levantamento do gênero do país, que no total inventariou 28 táxons, e por Bueno et al. (2011), que inventariaram 12 táxons para a região sul do país.

No presente estudo as características como a morfologia dos râmulos verticilados e a monoicia/ 
diocia foram relevantes na separação dos táxons. Contudo, muitos autores destacam que a taxonomia baseada apenas em caracteres morfológicos pode tornar a identificação de espécies em Characeae difícil e imprecisa, devido à ampla variação morfológica existente no grupo (Ray et al. 2001, Schneider et al. 2015). Segundo Vieira-Junior et al. (2003) alguns caracteres morfológicos muitas vezes são ineficazes para separação de táxons infraespecifico, uma vez que são fortemente influenciados pelas variações das condições ambientais.

Entretanto, estudos de ultraestrutura da parede do oósporo em MEV vêm sendo empregados na caracterização do grupo como uma ferramenta adicional, pois este auxilia na reinterpretação da ornamentação de oósporos descritos em MO, assim como utilizado para justificar ou rejeitar algumas mudanças taxonômicas realizadas por Wood \& Imahori (1965) (John et al. 1990, Casanova 1997, 2005, Ray et al. 2001, Mandal et al. 2002, Sakayama et al. 2009 e Urbaniak 2011). Dentre os vários aspectos do oósporo (largura, comprimento, fossa, estrias) o padrão de ornamentação da parede é considerado um dos mais importantes devido ao caráter conservado dessa estrutura (Ray et al. 2001).

No presente estudo, as análises ultraestruturais da parede do oósporo em MEV permitiu melhor caracterização do padrão de ornamentação, tendo em vista as interpretações equivocadas geradas pela limitação de foco e aumento em MO. Os táxons $C$. kenoyeri, C. rusbyana e C. hydropitys revelaram padrão granulado, como constatado também nas observações em MO. Contudo, em MEV foi possível evidenciar diferenças nas granulações: C. kenoyeri possuindo grânulos achatados e geralmente 2-3 unidos; C. rusbyana com grânulos projetados e $C$. hydropitys apresentando alguns grânulos com poros na região central.

Chara diaphana, C. zeylanica e C. martiana apresentam padrão em MEV distinto daqueles obtidos em MO, descritos como finamente granulado. Em MEV, C. diaphana e C. zeylanica apresentaram padrão pustulado, e C. martiana esponjoso. Acredita-se que o padrão finamente granulado visto em MO é resultado das perfurações das pústulas e dos espaços das anastomoses das fibrilas, reveladas em MEV.

O emprego de microscopia eletrônica subsidiou a interpretação da ultraestrutura da parede oósporo das espécies de Chara inventariadas demonstrando ser uma ferramenta valiosa na diagnose das espécies, permitindo, inclusive, diferenciar aquelas morfologicamente semelhantes como $C$. hydropitys e $C$ diaphana e $C$. rusbyana e C. kenoyeri. O presente estudo é o primeiro a descrever a ultraestrutura da parede do oósporo de C. martiana

Por fim, é importante ressaltar a necessidade de estudos florísticos de Characeae no estado da Bahia, bem como em outras da região Nordeste do Brasil, onde o conhecimento do grupo ainda é incipiente e muitas vezes restritos a checklists.

\section{Agradecimento}

Ao Conselho Nacional de Desenvolvimento Científico e Tecnológico, e à Fundação de Amparo à Pesquisa do Estado da Bahia (Projeto "Flora da Bahia", Processo No 483909/2012), o apoio financeiro; à Universidade Estadual de Feira de Santana, a infraestrutura disponibilizada e auxílios; a Maria Aparecida dos Santos e a Daniela da Silva Reis, a preciosa ajuda nas coletas do material. A primeira autora agradece ao $\mathrm{CNPq}$, a concessão da bolsa de Mestrado (Processo № 133387/2015.1).

\section{Referências}

Astorino HAB (1983) Charophyceae do estado do Rio Grande do Sul: uma contribuição ao seu inventário. Dissertação de Mestrado. Instituto de Biociências, Universidade Estadual Paulista, Rio Claro. 108p.

Bicudo RMT (1968) An annotated list of Charophyceae already cited for Brazil. Rickia 3: 221-238.

Bicudo RMT (1969) Brazilian Characeae of the Herbarium of the "Instituto de Botânica, São Paulo". Nova Hedwigia 17: 1-14.

Bicudo RMT (1972) O Gênero Chara (Chorophycae) no Brasil. Tese de Doutorado. Universidade de São Paulo, São Paulo. 229p.

Bicudo RMT (1974) O gênero Chara (Charophyceae) no Brasil, 1: subseção Willdenowia R.D. Wood. Rickia 6: 127-189.

Bicudo RMT (1977) O gênero Chara (Charophyceae) no Brasil, 2: seção Chara. Anais do $26^{\circ}$ Congresso Nacional de Botânica, Rio de Janeiro. Pp. 23-32.

Bicudo RMT (1979) O gênero Chara (Charophyceae) no Brasil, 1: seção Charopsis (Kütz. emend. Rupr., Leonh.) R.D. Wood. Rickia 8: 17-26.

Bicudo RTM \& Yamaoka DM (1978) O gênero Nitella (Charophyceae) no Brasil, 1: subgênero Nitella. Acta Biológica Paranaense 7: 77-98.

Borges FR \& Necchi-Junior O (2017) Taxonomy and phylogeny of Chara (Charophyceae, Characeae) from Brazil with emphasis on the midwest and southeast regions. Phytotaxa 302: 101-121.

Braun A \& Nordstedt CFO (1882) Fragmente einer Monographie der Characeen: nach den hinterlassenen Manuscripten. A Braun's herausgegeben von Dr. 
Otto Nordstedt. Abhandlungen der Königinen Akademie der Wissenschaftlichen Berlin 1882: 1-211.

Brummitt RK \& Powell CE (1992) Authors of plant names. The Royal Botanic Gardens, Kew. 732p.

Bueno NC, Bicudo CEM \& Picelli-Vicentim MM (1996) Characeae (Charophyceae) do Pantanal do Mato Grosso do Sul, Brasil: Chara. Hoehnea 23: 21-31.

Bueno NC, Bicudo CEM, Biolo S \& Meurer T (2009) Levantamento taxonômico das Characeae (Chlorophyta) de Mato Grosso e Mato Grosso do Sul, Brasil: Chara. Revista Brasileira de Botânica 32: 735-750.

Bueno NC, Prado JF, Meurer T \& Bicudo CEM (2011) New Records of Chara (Chlorophyta, Characeae) for Subtropical Southern Brazil. Systematic Botany 36: 523-541.

Menezes M, Bicudo CEM, Moura CWN, Alves AM, Santos AA, Pedrini AG, Araújo A, Tucci A, Fajar A, Malone C, Kano CH, Sant'Anna CL, Branco CZ, Odebrecht C, Peres CK, Neuhaus EB, Eskinazi-Leça E, Aquino E, Nauer F, Santos GN, Amado Filho GM, Lyra GM, Borges GCP, Costa IO, Nogueira IS, Oliveira IB, Paula JC, Nunes JMC, Lima JC, Santos KRS, Ferreira LC, Gestinari LMS, Cardoso LS, Figueiredo MAO, Silva MH, Barreto MBBB, Henriques MCO, Cunha MGGS, Bandeira-Pedrosa ME, Oliveira-Carvalho MF, Széchy MTM, Azevedo MTP, Oliveira MC, Cabezudo MM, Santiago MF, Bergesh M, Fujii MT, Bueno NC, Necchi Jr. O, Jesus PB, Bahia RG, Khader S, Alves-da-Silva SM, Guimarães SMPB, Pereira SMB, Caires TA, Meurer T, Cassano V, Werner VR, Gama Jr. WA \& da Silva WJ (2015) Update of the Brazilian floristic list of Algae and Cyanobacteria. Rodriguésia 66: 1047-1062.

Cáceres EJ (1979) Novedades carologicas II. Sobre el genero Chara (sect. Gymnobasalia) en Argentina. Kurtziana 12-13: 63-74.

Cartajena MG \& Carmona J (2009) Morphological and ecological characterization of Charales (Chlorophyta) from calcareous tropical streams in Mexico. Cryptogamie Algologie 30: 1.

Casanova MT (1997) Oospore variation in three species of Chara (Charales, Chlorophyta). Phycologia 36: 274-280.

Casanova MT (2005) An overview of Chara L. in Australia (Characeae, Chlorophyta). Australian Systematic Botany 18: 25-39.

Chalotra P, Gaind M \& Anand VK (2013) Morphotaxonomic studies of Chara zeylenica and based on sem studies of their oospores, growing in fresh waters of Jammu, J\&K. International Journal of Engineering Science Invention 2: 33-35.

Faegri K \& Iversen J (1989) Textbook of pollen analysis, $4^{\text {th }}$ ed. John Wiley, Chichester. 328p.

Groves J \& Bullock-Webster GR (1924) The British Charophyta. II. Chareae. The Ray Society, London. 129 p.
Henry-Silva GG, Santos RV, Moura RST \& Bueno NC (2013) Primeiro registro de Chara indica e Chara zeylanica (Charophyceae, Charales, Characeae) em reservatórios do semiárido do estado do Rio Grande do Norte, Brasil. Biotemas 26: 243-248.

John DM, Moore JA \& Green DR (1990) Preliminary observations on the structure and ornamentation of the oosporangial wall in Chara (Charales, Chlorophyta). British Phycological Journal 25: 1-24.

Krause W (1997) Charales (Charophyceae). In: Ettl H, Gärtner G, Heynig H \& Mollenhauer D (ed.). Süßwasserflora von Mitteleuropa, Band 18. Fischer, Jena. 202p.

Leitch AR, John DM \& Moore JA (1990) The oosporangium of the Characeae (Chlorophyta, Charales). Phycological Research 7: 213-68.

Mandal DK \& Ray S (2004) Taxonomic significance of micromorphology and dimensions of oospore in the genus Chara L. (Charales, Chlorophyta). Archives of Biological Sciences 56: 131-138.

Mandal DK, Blanzenzic J \& Ray S (2002) Sem study compound oospore wall ornamentation of some members of Charales from Yugoslavia, Croatia and Slovenia. Archives of Biological Sciences 54: 29-34.

Meiers ST, Proctor VW \& Chapman RL (1999) Phylogeny and biogeography of Chara (Chlorophyta) inferred from 18S rDNA sequences. Australian Journal of Botany 47: 347-360.

Meurer TS \& Bueno NC (2012) The genera Chara and Nitella (Chlorophyta, Characeae) in the subtropical Itaipu Reservoir, Brazil. Brazilian Journal of Botany 35: 219-232.

Necchi-Junior O, Branco CCZ \& Simões RCG (1995) Distribution of stream macroalgae in the northwest region of São Paulo state, southeastern Brazil. Hydrobiologia 299: 219-230.

Necchi-Junior O, Pascoaloto D \& Branco CCZ (1997) Stream macroalgal flora from the norwest region of São Paulo state, southeastern Brazil. Algological Studies 84: 91-112.

Necchi-Junior O, Branco CCZ \& Branco LHZ (2000) Distribution of stream macroalgae in São Paulo state, Southeastern Brazil. Algological Studies 97: 43-57.

Nowak P, Schubert H \& Schaible R (2016) Molecular evaluation of the validity of the morphological characters of three Swedish Chara sections: Chara, Gymnobasalia, and Gymnobasalia (Charales, Charophyceae). Aquatic Botany 134: 113-119.

Pérez W, Hall JD, McCourt RM \& Karol KG (2014) Phylogeny of North American Tolypella (Charophyceae, Charophyta) based on plastid DNA sequences with a description of Tolypella ramosissima sp. nov. Journal of Phycology 50: 776-789.

Picelli-Vicentim MM (1990) Characeae do estado de São Paulo: inventário sistemático. Tese de Doutorado. Instituto de Biociências, Universidade Estadual Paulista, Rio Claro. 256p. 
Picelli-Vicentim MM, Bicudo CEM \& Bueno NC (2004) Flora ficológica do estado de São Paulo, 5: Charophyceae. Editora RiMa, São Carlos. 124p.

Prado JF (2003) Characeae do Rio Grande do Sul, Brasil. Tese de Doutorado. Universidade Federal do Rio Grande do Sul, Porto Alegre. 275p.

Proctor VP, Griffin III DG \& Hotchkiss AT (1971) A synopsis of the genus Chara, series Gymnobasalia (subsection Willdenowia R.D.W.). American Journal of Botany 58: 894-901.

Ray S, Pekkari S \& Snoeijs P (2001) Oospore dimensions and wall ornamentation patterns in Swedish charophytes. Nordic Journal of Botany 21: 207-224.

Sabino JHF, Araújo ES, Cotarelli VM, Siqueira-Filho JA \& Campelo MJA (2015) Riqueza, composição florística, estrutura e formas biológicas de macrófitas aquáticas em reservatórios do semiárido nordestino, Brasil. Natureza on line 13: 184-194.

Sakayama H, Kasai F, Nozaki H, Watanabe MM, Kawachi M, Shigyo M, Nishihiro J, Washitani I, Krienitz L \& Ito M (2009) Taxonomic reexamination of Chara globularis (Charales, Charophyceae) from Japan based on oospore morphology and rbcL gene sequences, and the description of C. leptospora sp. nov. Journal of Phycology 45: 917-927.

Schneider SC, Rodrigues A, Moe TF \& Ballot A (2015) DNA barcoding the genus Chara: molecular evidence recovers fewer taxa than the classical morphological approach. Journal of Phycology 51: 367-380.

Schneider SC, Nowak P, Von Ammon U \& Ballot A (2016) Species differentiation in the genus Chara (Charophyceae): considerable phenotypic plasticity occurs within homogenous genetic groups. European Journal of Phycology 262: 1-12.
Siqueira-Filho J \& Bueno NC (2012) A flora das caatingas do Rio são Francisco. In: Siqueira-Filho JA (ed) Flora das caatingas do Rio São Francisco. Vol. 1. Andrea Jakobsson Estúdio Editorial Ltda, Rio de Janeiro. Pp. 445-543

Torgan LC, Barreda KA \& Fortes DF (2001) Catálogo das algas Chlorophyta de águas continentais do estado do Rio Grande do Sul, Brasil. Iheringia: série Botânica 56: 147-183.

Urbaniak J (2011) A SEM and light microscopy study of the oospore wall ornamentation in Polish charophytes (Charales, Charophyceae) genus Chara. Nova Hedwigia 93: 1-28.

Urbaniak J \& Combik M (2017) Taxonomic status of Chara tenuspina A. Br. (Streptophyta: Charales) based on LM morphology, matK, atpB and rbcL of cpDNA sequences. Fottea, Olomouc 17: 20-33.

Vieira-Junior J, Necchi-Junior O, Branco CCZ \& Branco LHZ (2002) Characeae (Chlorophyta) de ecossistemas lóticos do estado de São Paulo, Brasil, 1: gênero Nitella. Hoehnea 29: 249-266.

Vieira-Junior J, Necchi-Junior O, Branco CCZ \& Branco LHZ (2003) Characeae (Chlorophyta) de ecossistemas lóticos do estado de São Paulo, Brasil, 2: gênero Chara e distribuição ecológica. Hoehnea 30: 53-70.

Wood RD (1962) New combinations and taxa in the revision of Characeae. Taxon 11: 7-25.

Wood RD \& Imahori K (1964) A revision of the Characeae, 2: iconograph of the Characeae. J. Cramer, Weinhen. 797p.

Wood RD \& Imahori K (1965) A revision of the Characeae, 1: monograph of the Characeae. J. Cramer, Weinhen. 904p.

Zaneveld JS (1940) The Charophyta of Malaysia and adjacent countries. Blumea 4: 1-224. 